\title{
The basal dunite of the Precambrian mafic-ultramafic Näränkävaara intrusion: Petrogenetic considerations and implications to exploration
}

\author{
Ville Järvinen $^{1}$ (D) $\cdot$ Tapio Halkoaho $^{2} \cdot$ Jukka Konnunaho $^{3} \cdot$ Jussi S. Heinonen ${ }^{1} \cdot$ O. Tapani Rämö ${ }^{1}$ \\ Received: 17 March 2020 / Accepted: 16 September 2020 / Published online: 10 November 2020 \\ (C) The Author(s) 2020
}

\begin{abstract}
Several mafic-ultramafic layered intrusions were emplaced in the Fennoscandian Shield during wide-spread mantle-sourced magmatism at 2.5-2.4 Ga. The Näränkävaara intrusion (surface area $5 \times 30 \mathrm{~km}^{2}$ ), northeastern Finland, contains a 1.5-2 km thick basal dunite (not dated), and a $1.5 \mathrm{~km}$ thick layered series ( $2436 \pm 5 \mathrm{Ma}$ ). A newly discovered marginal series between the basal dunite and the layered series indicates that the basal dunite is older, and highlights the need for further study on their relationship. Along its southern basement contact, the basal dunite contains a 200-300 m thick zone of olivine ortho- and mesocumulates, but the bulk of it is composed of olivine adcumulates and lesser olivine-orthopyroxene heteradcumulates. Based on whole-rock geochemistry, the basal dunite is divided into a low-Fe zone (average $\mathrm{FeO}_{\mathrm{t}} 10.2 \mathrm{wt} \%$ and $\mathrm{Ni} 2250 \mathrm{ppm}$ ) and a high-Fe zone (average $\mathrm{FeO}_{\mathrm{t}} 12.5 \mathrm{wt} \%$ and $\left.\mathrm{Ni} 1700 \mathrm{ppm}\right)$. Both zones have high $\mathrm{MgO}(32-47 \mathrm{wt} \%)$ and varying $\mathrm{Cr}(830-5160 \mathrm{ppm})$ and $\mathrm{Al}_{2} \mathrm{O}_{3} / \mathrm{TiO}_{2}$ (16-26). Textural and geochemical layering is similar along the $30 \mathrm{~km}$ strike of the basal dunite. A LREE-enriched high-MgO basaltic parental magma composition $(13-18 \mathrm{wt} \% \mathrm{MgO})$ is inferred for the basal dunite from olivine-melt mixing trends in orthocumulates. The dunite exhibits at least two geochemical reversals as well as abundant low-porosity adcumulates, poikilitic chromite, and bimodal olivine, suggesting formation in a high-volume open magmatic system. Significant similarity in major and trace element compositions with the Näränkävaara layered series and the Burakovsky intrusion and Vetreny belt extrusives in Russian Karelia suggests that the basal dunite belongs to the Fennoscandian 2.5-2.4 Ga mafic layered intrusions. An Archean komatiitic origin for the dunite body cannot be completely ruled out, however. Distinct Ni-depletion in olivine is found in the basal dunite from the low-Fe zone to the high-Fe zone (3200 versus $2200 \mathrm{ppm}$ ). This depletion does not correlate with Fo contents, which suggests that it is not related to olivine fractionation. The basal dunite may thus have potential for $\mathrm{Ni}-(\mathrm{Cu}-\mathrm{Co}-$ PGE) sulfide mineralization.
\end{abstract}

Keywords Tonio-Näränkävaara belt $\cdot$ Näränkävaara $\cdot$ Layered intrusion $\cdot$ Dunite $\cdot$ Komatiite $\cdot$ Ni-criticality

Editorial handling: L. Nasdala

Electronic supplementary material The online version of this article (https://doi.org/10.1007/s00710-020-00725-9) contains supplementary material, which is available to authorized users.

Ville Järvinen

ville.jarvinen@helsinki.fi

1 Department of Geosciences and Geography, University of Helsinki, Gustaf Hällströmin katu 2 (Physicum), P.O. Box 64, 00014 Helsinki, Finland

2 Geological Survey of Finland, Neulaniementie 5, P.O. Box 1237, 70211 Kuopio, Finland

3 Geological Survey of Finland, Lähteentie 2, P.O. Box 77, 96101 Rovaniemi, Finland

\section{Introduction}

The Tornio-Näränkävaara intrusive belt (TNB) in northern Finland is critical for orthomagmatic PGE-Ni-Cu-Co and Cr-V-Ti-Fe deposits (Huhtelin 2015; Iljina et al. 2015; Makkonen et al. 2017). The easternmost of these $2.44 \mathrm{Ga}$ layered intrusions (Iljina and Hanski 2005) is the mafic-ultramafic Näränkävaara intrusion (Fig. 1). The geology and mineral potential of the Näränkävaara intrusion is still relatively poorly known (Alapieti 1982; Järvinen et al. 2020). The presence of a large mass of ultramafic cumulates below the layered series of the Näränkävaara intrusion (Fig. 2a) has been known since the 1960's (Auranen 1969), but the petrogenesis, mineral potential, and relationship of this basal dunite with 


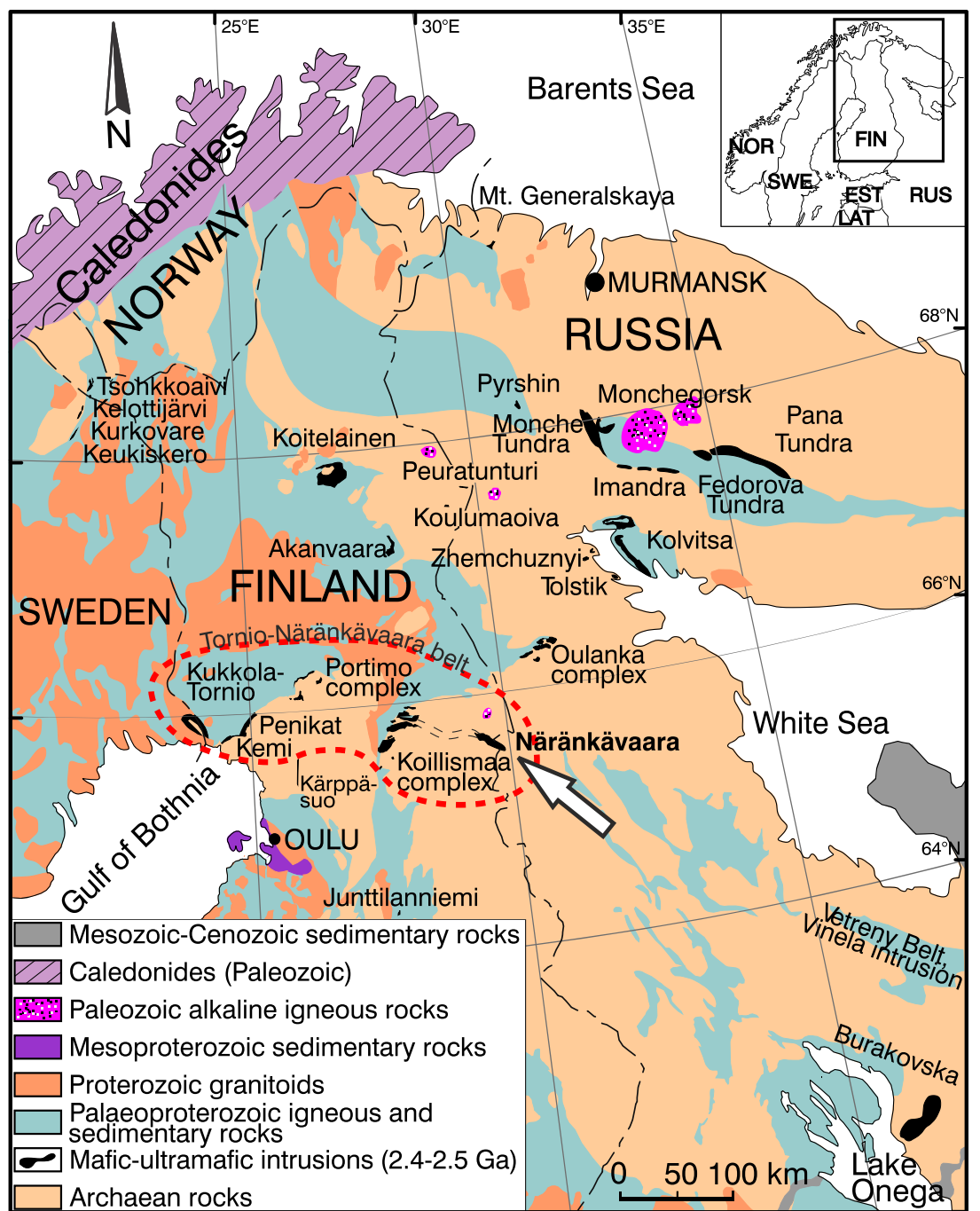

Fig. 1 Map of 2.53-2.39 Ga mafic-ultramafic layered intrusions of the Fennoscandian Shield. The Tornio-Näränkävaara belt is outlined with a red dashed line, and a white arrow points out Näränkävaara. The Koillismaa complex includes the tectonically dismembered western

the neighboring layered series have not been resolved. More recent mineral exploration projects have reported the basal dunite to be composed of homogeneous, $\sim 2 \mathrm{~km}$ thick olivine adcumulate, and to be continuous for the $30 \mathrm{~km}$ length of the intrusion (Fig. 2a) (Iljina 2003; Vesanto 2003; Lahtinen 2005). The basal dunite exhibits several features commonly thought of as komatiitic, being mostly composed of tightly packed monomineralic olivine adcumulate, sometimes with bimodal olivine and poikilitic chromite (cf. Barnes and Hill 1995). The recent discovery of a marginal series between the Näränkävaara layered series and the basal dunite indicates that the basal dunite must be at least marginally older (Järvinen et al. 2020).

Here, the Näränkävaara basal dunite is hypothesized to represent either a feeder channel cumulate related to the same Fennoscandian 2.5-2.4 Ga magmatism as the intrusions and Näränkävaara to the east, connected by a positive magnetic and gravity anomaly presumed to be a "hidden dyke" (thin black dashed line) (map modified after Alapieti 1982)

2436 Ma Näränkävaara layered series (Fig. 2a) (Alapieti 1982; Kulikov et al. 2010), or an older komatiitic wallrock for the layered series extending into the Näränkävaara area from the nearby Archean Takanen or Suomussalmi greenstone belts (Iljina 2003; Papunen et al. 2009; Mikkola et al. 2011). Mantle-derived ultramafic cumulates are known to host orthomagmatic sulfide deposits (e.g. Begg et al. 2010; Barnes et al. 2016a); in the former case it could have potential for magmatic sulfide mineralizations linked to feeder channel cumulates, such as in Jinchuan (Chai and Naldrett 1992), and in the latter case for komatiite-hosted sulfide mineralizations (Konnunaho 2016; Makkonen et al. 2017).

New drilling and mapping was conducted in the Näränkävaara basal dunite during $2017-2018$ by the Geological Survey of Finland (GTK) (Halkoaho et al. 2019). Based on these new results and a compilation of pre-existing 

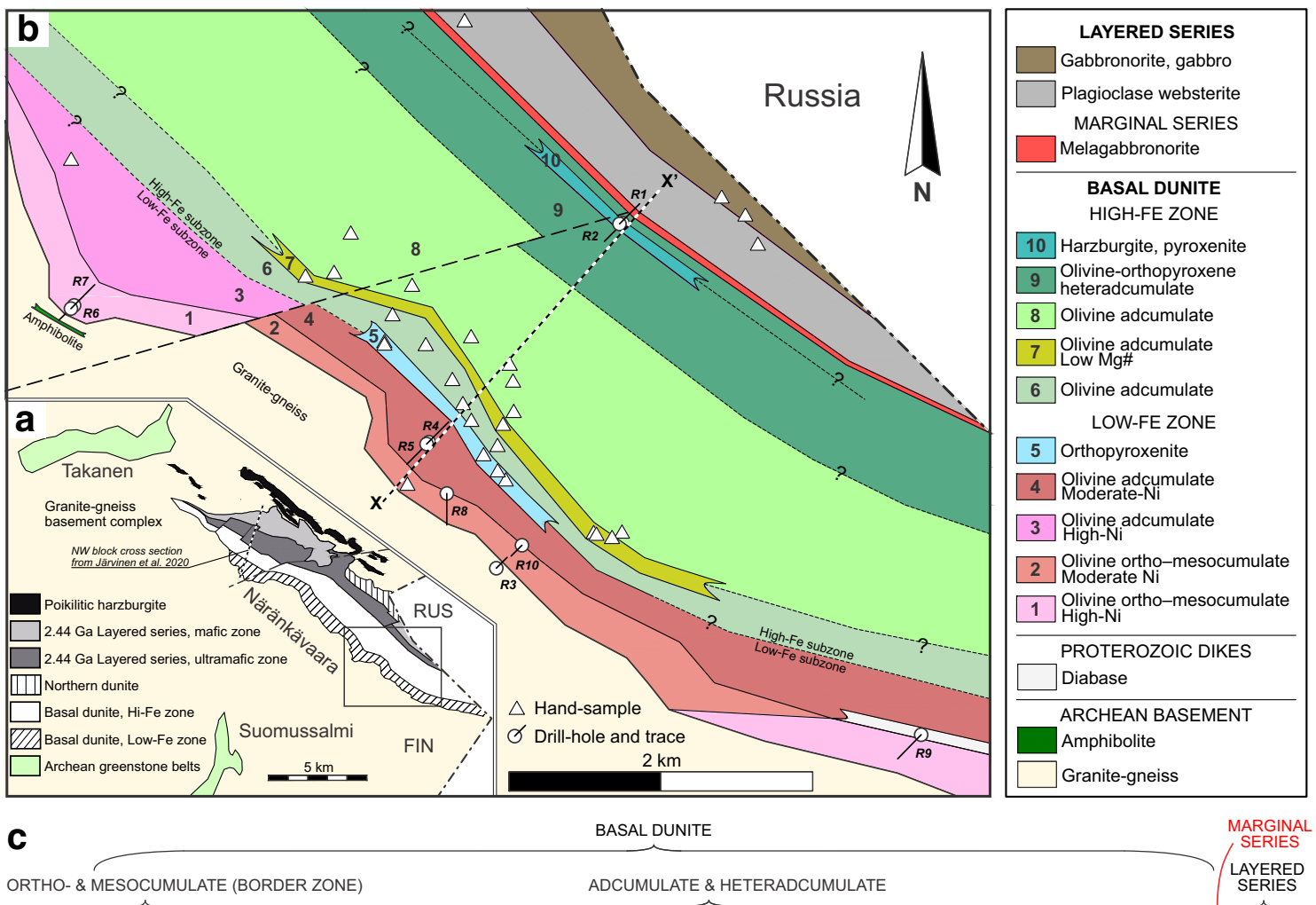

Granite-gneiss

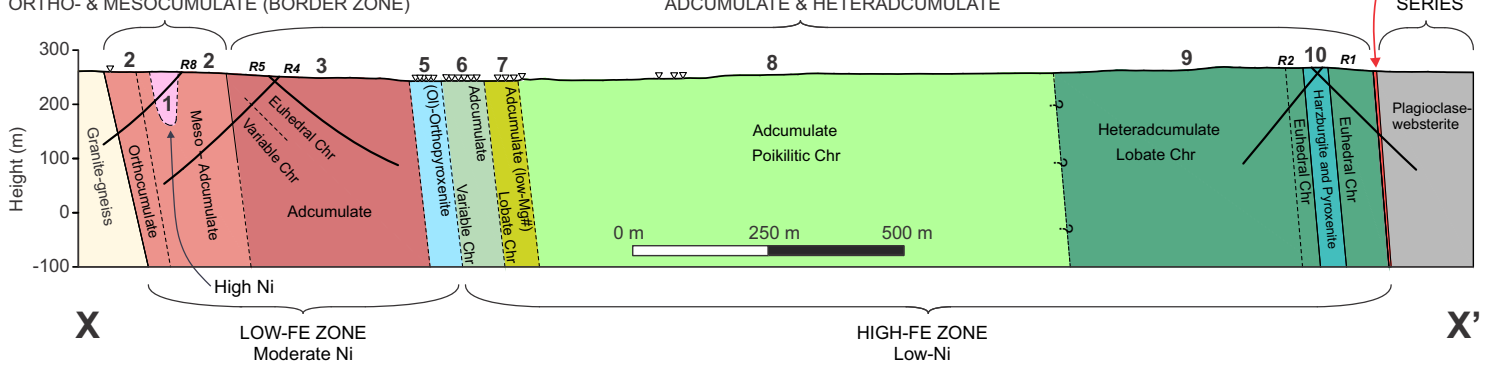

Fig. 2 a Simplified geological map of the Näränkävaara intrusion. The intrusion continues about $2 \mathrm{~km}$ into Russia; b Geological map of the SE block of the Näränkävaara basal dunite with locations of new drill holes (R1-R10) and surface samples (white triangles); c Cross-section $X-X^{\prime}$ along the Näränkävaara basal dunite, with the SW basement contact to the left. Contacts are mostly unexposed and extrapolated from known contacts or inferred from geophysical measurements. Note that most geochemical diagrams in this paper are plotted with the same unit colors as are used here

intracontinental paleoplate boundaries in the Archean Karelia and Kola cratons (Bayanova et al. 2009; Kulikov et al. 2010; Tiira et al. 2014).

The five intrusions and intrusion complexes comprising the TNB have an average age of 2.44 Ga (Fig. 1) (Iljina and Hanski 2005). They are typical layered intrusions with a layered and marginal series, and are divided into three compositional groups: (1) mafic-ultramafic, which contain a peridotitic-pyroxenitic lower zone (Näränkävaara and Kemi), (2) mafic, which are dominated by gabbronoritic rocks (Koillismaa), and (3) megacyclic (Penikat and Portimo), which are characterized by macrorhythmic compositional reversals (Alapieti and Lahtinen 2002). Stratigraphically, the intrusions of the TNB are found at the contacts of late Archean granitoids and overlying Paleoproterozoic supracrustal rocks (Alapieti et al. 
1990). In contrast to other intrusions of the TNB, the Näränkävaara intrusion is completely surrounded by the Archean granite-gneiss basement complex (Fig. 1) (Hölttä et al. 2012). In addition, Näränkävaara is the only intrusion in the TNB associated with voluminous dunitic cumulates (Alapieti 1982; Järvinen et al. 2020).

The parental magmas of the Finnish 2.5-2.4 Ga mafic layered intrusions are thought to be (boninite-like) siliceous high-Mg basalts (Alapieti et al. 1990; Iljina and Hanski 2005). Wholerock and isotope geochemical systematics (average initial $\varepsilon_{\mathrm{Nd}}$ of -2) point to crustal contamination of primitive magmas from a mantle plume source (Puchtel et al. 1997; Hanski et al. 2001; Vuollo and Huhma 2005; Yang et al. 2016; Rämö et al. 2017; Maier et al. 2018). Intrusive and extrusive formations with similar compositions are found in Russian Karelia, for example the komatiitic basalts and dykes of the Vetreny belt, and the maficultramafic Burakovsky layered intrusion (Fig. 1) (Puchtel et al. 1997; Chistyakov and Sharkov 2008).

The Näränkävaara layered intrusion has been included as a part of the Koillismaa layered intrusion complex (KLIC) (Alapieti 1982). The KLIC comprises (1) the tectonically dismembered western intrusion blocks of the Koillismaa layered intrusion (Karinen 2010), (2) the eastern Näränkävaara intrusion, and (3) a strong positive gravity and magnetic anomaly connecting the first two (dashed line in Fig. 1). Alapieti (1982) interpreted the Koillismaa and Näränkävaara intrusions to be cogenetic, with the Näränkävaara intrusion representing the lowest exposed stratigraphic level of the KLIC. The connecting geophysical anomaly - hitherto not intersected in drilling - was thought to be a magmatic conduit that fed the two intrusions. The recently discovered (likely Archean) Takanen schist belt (Fig. 2a) coincides with the geophysical anomaly (Iljina 2003; Salmirinne and Iljina 2003; Iljina et al. 2006).

\section{Geology of the Näränkävaara intrusion}

The mafic-ultramafic Näränkävaara intrusion (Fig. 2a) is mostly unexposed but shows as a strong positive magnetic anomaly about $30 \mathrm{~km}$ long and $5 \mathrm{~km}$ wide, with the basal dunite also being highly and untypically conductive (Niskanen and Jokinen 2018). Gravimetric and magnetometric measurements indicate that the intrusion extends to a depth of 5-10 km (Elo 1992; Salmirinne and Iljina 2003). A large SW-NE trending fault separates the Näränkävaara intrusion into two blocks (NW and SE block).

The intrusion comprises the following three distinct igneous bodies (or series) that are partly or dominantly composed of ultramafic cumulates (Fig. 2a): (1) The southernmost unit consists of a 1-2 km thick basal dunite (not dated thus far) that is composed of dunite and minor peridotite and pyroxenite (Vesanto 2003; Järvinen et al. 2020). This unit is in the focus of the present study. (2) The central, $2436 \pm 5 \mathrm{Ma}(2 \sigma)$ old
Näränkävaara layered series is composed of a $700 \mathrm{~m}$ thick peridotitic-pyroxenitic ultramafic zone, and a $600 \mathrm{~m}$ gabbroic-dioritic mafic zone (Alapieti 1982). In the SE block of the intrusion, a poorly developed $10 \mathrm{~m}$ thick gabbronoritic marginal series was recently found in the contact between the basal dunite and the layered series, grading into the layered series (Järvinen et al. 2020). (3) A series of smaller elongate intrusions runs parallel to the northern contact of the layered series and composed of poikilitic harzburgite (Alapieti et al. 1979). These northern harzburgites have been drilled (Iljina 2003) but have not been investigated in detail.

In the layered series, the dip of igneous layering in the NW block is $20^{\circ}$ to the NE, while in the SE block it is $5-15^{\circ}$ to the SW (Fig. 2a) (Alapieti et al. 1979). In addition to the large fault splitting the intrusion, there are several strike-slip faults along the short axis of the body, and dip-slip faults with strikes along the long axis. Apart from faulting the intrusion is mostly undeformed. The layered series is relatively unaltered, whereas the basal dunite is thoroughly serpentinized.

One previous drilling profile located in the NW block of the intrusion intersects the basal dunite, but includes several gaps up to $600 \mathrm{~m}$ in thickness. Järvinen et al. (2020) divided the basal dunite along this NW cross section into three olivine cumulate units (see Fig. S1 in electronic supplementary material), from south to north: (1) a harzburgitic olivine mesocumulate transition zone in contact with the basement complex and characterized by distinctly higher contents of incompatible elements compared to the other two units, (2) a homogeneous olivine adcumulate center section characterized by relatively low $\mathrm{Cr}$ contents (1000-1500 ppm Cr) compared to the other two units (2000-4000 ppm Cr), and (3) an olivine ad- to mesocumulate unit characterized by coarse poikilitic orthopyroxene, in contact with the layered series. Orientation of igneous layering in the NW block of the basal dunite is poorly constrained, but is assumed to be subvertical at the southern basement contact and to get shallower towards the north, being about $45^{\circ}$ at the basal dunite-layered series contact. No gabbronoritic marginal series is found at this contact in the NW block, unlike in the SE block.

In addition to the previously mentioned cumulate units, $600 \mathrm{~m}$ of homogeneous olivine adcumulate was intersected in one drill hole on the northern side of the layered series in the SE block of the intrusion (indicated as 'northern dunite' in Fig. 2a) (Akkerman 2008). This northern dunite has a much lower $\mathrm{Al}_{2} \mathrm{O}_{3} / \mathrm{TiO}_{2}$ ratio than the main basal dunite body on south side of the layered series (average of 7 versus 21), and has not been found elsewhere.

\section{Materials and methods}

The materials for this study were obtained during new drilling and mapping activities by the Geological Survey of Finland in 
2017-2018 (Halkoaho et al. 2019). New drilling and sampling is located in the SE block of the Näränkävaara intrusion, and comprises 10 drill holes with $2380 \mathrm{~m}$ of drill core and 109 analyzed whole-rock samples (drill holes R1-R10 in Fig. 2b), and 18 surface samples. Pre-existing data has been taken into consideration for purposes of petrographical and geochemical correlations and interpretations, but has generally not been plotted in diagrams for sake of clarity. All sample materials used, and sources used for data compilation, are listed in Table S1.

Full whole-rock analysis results, method descriptions, detection limits, and calibration materials used are listed in Table S2. Explanations of method codes and method descriptions can also be found in the reference Labtium Oy (2015). Major and some minor elements were determined with a Panalytical Axios PW 4400 X-ray fluorescence (XRF) spectrometer from pressed powder pellets (Labtium Oy method code 176X). Platinum, Pd and $\mathrm{Au}$ were determined by $\mathrm{Pb}$-fire assay fusion followed by graphite furnace atomic absorption spectrometry (GFAAS; method code $704 \mathrm{U}$ ). For the rare-earth elements (REE) and some trace elements, sample solutions were prepared by HF$\mathrm{HClO}_{4}$ digestion and lithium metaborate-sodium perborate fusion, followed by inductively coupled plasma mass spectrometry (ICP-MS) with a Thermo Electron iCAP Qc (method $308 \mathrm{M}$ ), or optical emission spectrometry (ICP-OES) with a Thermo Electron iCAP 6500 (method 308P), with final results calculated as an average of three replicate analyses. For all analysis methods, duplicate analyses were made for 5\% of samples, with a coefficient of variation generally below $5 \%$. All results of whole-rock analyses presented in this study are normalized to volatile-free $100 \mathrm{wt} \%$.

For parental magma modeling, and for calculating wholerock $\mathrm{Mg} \#\left[\mathrm{Mg} \#=\mathrm{Mg} /\left(\mathrm{Mg}+\mathrm{Fe}^{2+}\right)\right]$, whole-rock $\mathrm{Fe}_{2} \mathrm{O}_{3} / \mathrm{FeO}$ ratios have been calculated from total $\mathrm{FeO}\left(\mathrm{FeO}_{t}\right)$ according to the method of Barnes et al. (2007). This method was developed for pure olivine adcumulates (komatiites) where $\mathrm{Fe}_{2} \mathrm{O}_{3}$ contents is assumed to be zero, as $\mathrm{Fe}^{3+}$ is incompatible in olivine. A linear increase in whole-rock $\mathrm{Fe}_{2} \mathrm{O}_{3} / \mathrm{FeO}$ ratio from 0 to 0.1 is calculated as a function of decreasing modal olivine and increasing liquid component. Olivine mode is proxied using whole-rock $\mathrm{MgO}$ contents, so that a $\mathrm{Fe}_{2} \mathrm{O}_{3} / \mathrm{FeO}$ ratio of 0.1 results at $<25 \mathrm{wt} \% \mathrm{MgO}$, and a ratio of 0 at $>50 \mathrm{wt} \%$ $\mathrm{MgO}$, with a constant linear variation in the ratio in between (Barnes et al. 2007).

Petrography of 208 thin sections were examined with crosspolarised transmitted-light microscopy. Chemical compositions of minerals from the SE block of the Näränkävaara body were analyzed by wavelength dispersive spectroscopy with a Cameca SX100 electron probe micro-analyzer (EPMA) (464 spot analyses from 225 mineral grains from 40 thin sections). Full results along with analyzing conditions, X-ray lines analysed and calibration materials used are listed in Table S2. Standard deviation based on repeated standard measurements is $<1 \%$. Chromite analyses have been recalculated assuming stoichiometry to an ideal $\mathrm{XY}_{2} \mathrm{O}_{4}$ formula according to Barnes (1998) [with $\mathrm{X}=\left(\mathrm{Fe}^{2+}, \mathrm{Ni}, \mathrm{Mn}, \mathrm{Co}, \mathrm{Zn}\right)$ and $\left.\mathrm{Y}=\left(\mathrm{Cr}, \mathrm{Fe}^{3+}, \mathrm{Al}\right)\right]$.

\section{Results}

\section{Generalities}

Eight of the ten new drill holes are located along the southern contact between the basal dunite and the basement complex (R3-R10 in Fig. 2b), and two drill holes are located at the northern contact between the basal dunite and the layered series (R1-2 in Fig. 2b), with surface samples in between (white triangles in Fig. 2b). Based on this new sampling, a new geological map and cross section of the SE block of the Näränkävaara intrusion is presented in Figs. $2 b$ and c. The basal dunite is subdivided into ten units based on differences in petrography and whole-rock geochemistry as described below. These units are numbered 1-10 in Fig. $2 \mathrm{~b}$ and c, and their characteristics are summarized in Table 1 . The cross section in Fig. 2 spans a horizontal length of $2500 \mathrm{~m}$, but includes horizontal gaps of up to $1000 \mathrm{~m}$ between sample points due to lack of sampling in the center of the basal dunite. Even with poor sampling density, it is possible to correlate this cross section with the previous cross section from the NW block of the intrusion by similarities in whole-rock compositions and petrography (Fig. S1; Järvinen et al. 2020).

We have aimed to use cumulus terminology descriptively according to Irvine (1982), without genetic connotations to the intrusive or extrusive origin of the rocks. A cumulate consists of varying amounts of accumulated (near) liquidus crystals and trapped intercumulus melt. An adcumulate contains $>93 \mathrm{vol} \%$ accumulated crystals, mesocumulate $93-75$ vol\%, and orthocumulate $75-50$ vol $\%$. In the basal dunite, adcumulates are typically dunites and meso- and orthocumulates are harzburgites and lherzolites. A heteradcumulate is a cumulate with a poikilitic texture and a very minor component of recognizable trapped intercumulus melt (Wager et al. 1960; Barnes et al. 2016b). The presence of trapped intercumulus melt in olivine and orthopyroxene rich cumulates, like found in Näränkävaara, can usually be recognized from elevated contents of incompatible elements (e.g., $\mathrm{Al}, \mathrm{Ti}, \mathrm{P}, \mathrm{Zr}$ ) in whole-rock analysis. As such, adcumulate and heteradcumulate rocks tend to exhibit adcumulate chemistries poor in incompatible elements, and orthocumulate rocks tend to exhibit orthocumulate chemistries relatively rich in incompatible elements.

\section{Petrography of the basal dunite}

\section{Ortho- and mesocumulates of the SW border zone}

A $200-400 \mathrm{~m}$ thick border zone composed of olivine orthoand mesocumulates and minor adcumulates (units \#1-2 in 


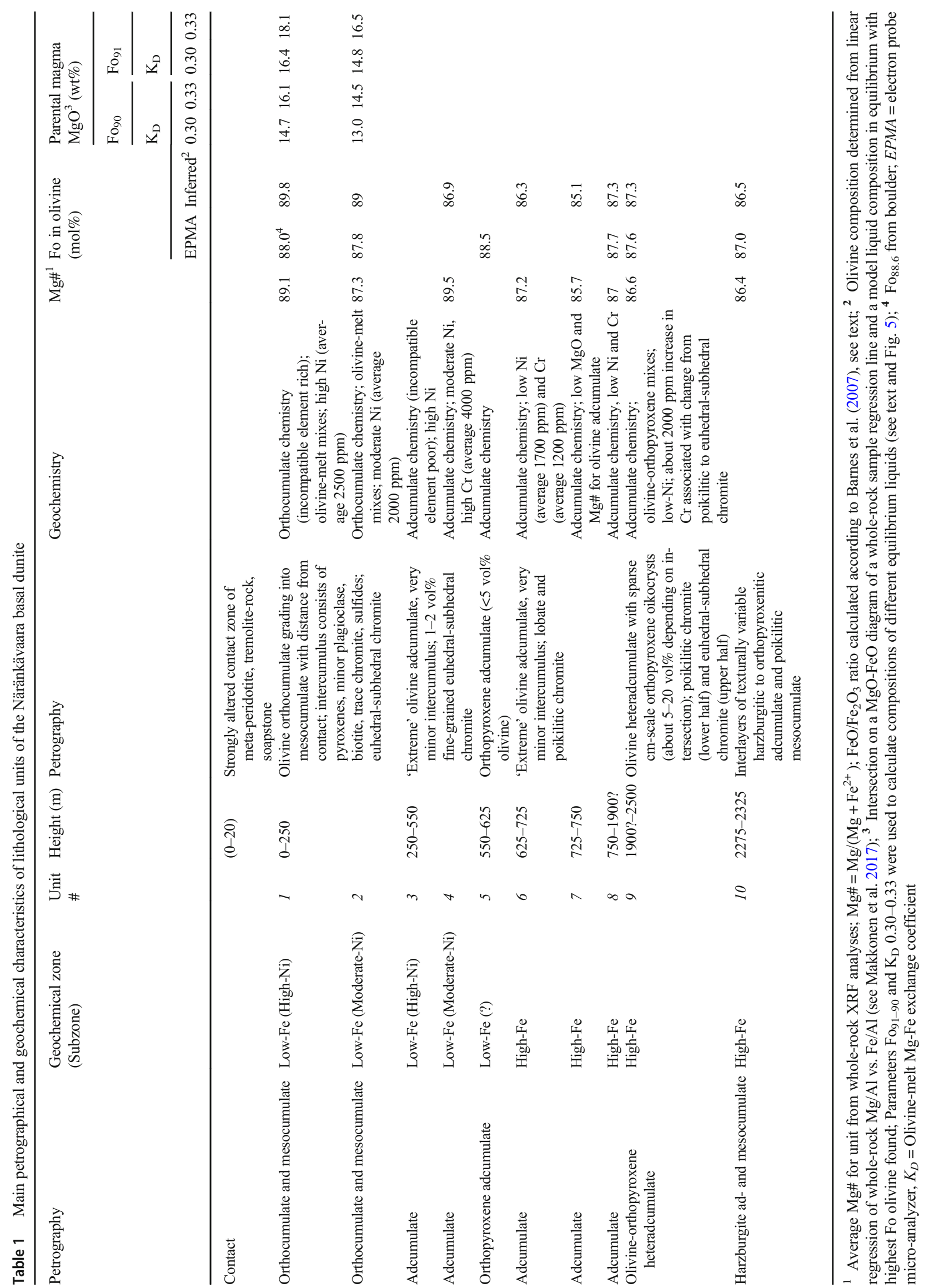


Fig. 2 and Table 1) is found all along the SW contact between the basal dunite and the Archean basement complex. The basement contact is subvertical or dips steeply to the NE $\left(75-90^{\circ}\right)$. The granite-gneiss basement is hornfelsed for a depth of at least $0.5 \mathrm{~m}$, and leached and broken for up to $5 \mathrm{~m}$ from the contact. The immediate contact zone is $<20 \mathrm{~m}$ thick and composed of fine grained metaperidotites and tremolite chlorite schists. The tremolite schists are intensely sheared and have probably acted as a deformational buffer zone for post-emplacement tectonic movements. Degree of alteration rapidly decreases with distance from contact. Meter-scale basement xenoliths and decimeter-scale potassic to dioritic veins derived from partially molten basement are sometimes found up to $250 \mathrm{~m}$ away from the contact.

The olivine ortho- and mesocumulates forming the main mass of the border zone (units \#1-2) are strongly serpentinized but with undeformed fabrics, showing relict cumulus textures with pseudomorphs after olivine (Fig. 3a and b). Rare samples contain unaltered olivine and pyroxenes. Amount of olivine increases with distance from the basement contact, from about 40-60 vol\% to 90-95 vol\% over 200-300 m. Olivine grain size is typically between $0.5-3 \mathrm{~mm}$, but intersections with coarser up to $10 \mathrm{~mm}$ grains are found in all drill holes. Olivine occasionally defines magmatic lamination (Fig. 3b). An evenly distributed network of intercumulus material is characteristic for these rocks (Fig. 3a and b). Intercumulus consists of orthopyroxene and lesser clinopyroxene, with minor phlogopite and plagioclase. Pyroxenes are poikilitic with grain sizes between 5 and $10 \mathrm{~mm}$ (Fig. 3a). Fine-grained euhedral-subhedral chromite typically appears in trace amounts $(0.5-2 \mathrm{vol} \%)$. Chromite is also found as inclusions in olivine.

Sulfides with primary magmatic textures are very rarely found, whereas trace amounts of fine-grained disaggregated sulfides (metamorphic or remobilized) are common. Trace amounts of very fine-grained $\mathrm{Fe}-\mathrm{Ni}-\mathrm{Cu}$ sulfides were commonly found during preliminary EPMA mineral analyses, either as discrete grains or intergrown with oxides. No Pt or Pd phases were found except for one $1 \mu \mathrm{m}$ grain.

\section{Adcumulates and heteradcumulates}

Decrease of intercumulus material to small isolated pockets (typically $<3 \mathrm{vol} \%$ ) marks the beginning of the approximately $2000 \mathrm{~m}$ thick main adcumulate mass of the basal dunite (units
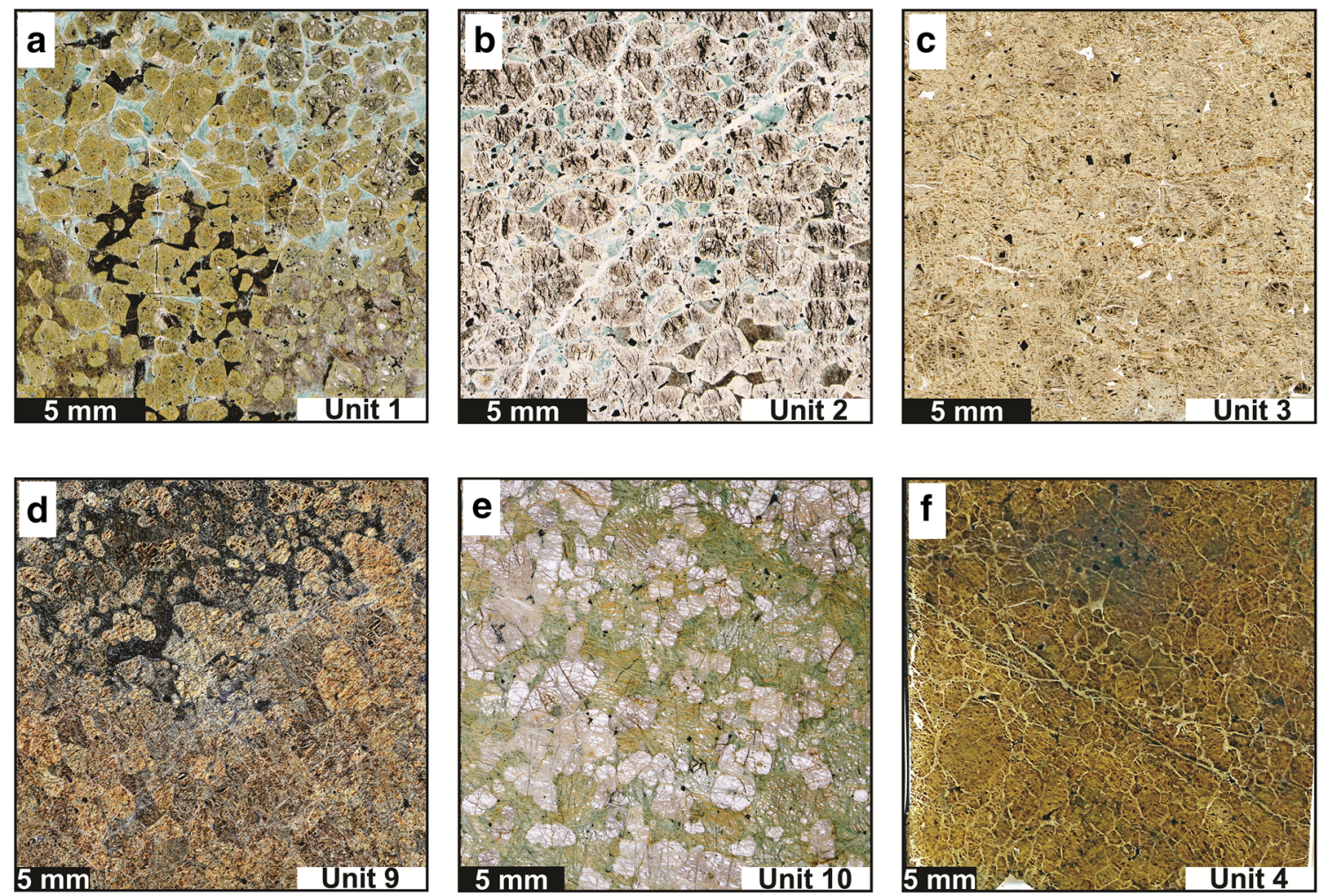

Fig. 3 a-f Plane-polarized light photomicrographs showing thin-sections of main rock-types in the Näränkävaara basal dunite; length of black scale-bar is $5 \mathrm{~mm}$; a Border zone orthocumulate (unit \#1); serpentinized cumulus olivine with intercumulus showing dark poikilitic pseudomorphs after pyroxene (sample R6 $89.80 \mathrm{~m}$ ); b Border zone mesocumulate (unit \#2) exhibiting magmatic lamination along horizontal plane (sample R7 $157.20 \mathrm{~m}$ ); c Ni-rich olivine adcumulate from low-Fe zone (unit \#3) with euhedral and interstitial chromite (sample VJJA-88); d Olivine orthopyroxene heteradcumulate (unit \#9) with a dark poikilitic orthopyroxene pseudomorph enclosing tightly packed serpentinized olivine (sample R2 72.30); e Harzburgitic adcumulate interlayer (unit \#10) close to contact with layered series (sample R2 $30.40 \mathrm{~m}$ ); f Olivine adcumulate from the NW block of the Näränkävaara intrusion, high-Fe zone, showing bi-modal olivine and interstitial to lobate chromite (correlates to units \#6-8 in the SE block; image is a scanned thin section; sample R303 $127.43 \mathrm{~m}$ ) 
\#3-10 in Fig. 2 and Table 1). It is composed of olivine adcumulates and minor orthopyroxenites in the SW (units \#38), followed by olivine-orthopyroxene heteradcumulate and minor orthopyroxenites in the NE (units \#9-10). Olivine adcumulate textures range from subhedral (Fig. 3c) to tightly packed polygonal (lower half of Fig. 3d). Olivine is typically equigranular with grain size between $0.5-3 \mathrm{~mm}$, but rare bimodal olivine is also found in the NW block of the dunite (Fig. 3f). The orthocumulate border zone (units \#1-2) most likely grades into the adcumulates, but this boundary is only intersected in one drill hole (R5), where it coincides with a $1 \mathrm{~m}$ thick olivinepegmatoidal layer, composed of loosely packed $\mathrm{cm}$-sized subhedral olivine pseudomorphs in a fine grained serpentine groundmass. No other magmatic layering has been identified in the adcumulates, and for the most part the inner structure of the SE block of the basal dunite is poorly constrained.

A $<200 \mathrm{~m}$ thick unit of fresh (olivine) orthopyroxene adcumulate (unit \#5 in Fig. 2 and Table 1) is found sandwiched between two olivine adcumulate units. This orthopyroxenite unit is notable in two ways. First, it marks the border between the geochemically defined low-Fe and high-Fe zones, as discussed later. Second, a change in chromite textures seems to be associated with the stratigraphic level of this unit. It has been argued that all chromites in ultramafic cumulates are cumulus in origin, i.e., a liquidus phase, regardless of their crystal habit (Barnes 1998; Godel et al. 2013), and thus the terms cumulus and intercumulus are avoided for describing chromite textures. In this study, chromites have been classified as euhedral-subhedral (upper grain in Fig. 4b), interstitial (weakly growing between cumulus grains; lower grain in Fig. 4b, also Fig. 3c), lobate (more extensive fingering between cumulus grains; Fig. 4c), and poikilitic (completely enclosing adjacent grains; Fig. 4d). As labeled in Fig. 2c, below the orthopyroxenite unit (in units \#14) chromite textures are fine grained euhedral or interstitial, whereas above the orthopyroxenite (in units \#6-9) chromite textures are typically lobate or poikilitic. These systematics continue up to the middle of unit \#9, where chromite texture changes back to euhedral. In the basal dunite, olivine cumulates with most abundant chromite (up to 1-2 vol\%) always show euhedral-subhedral chromite textures. Poikilitic chromite is notably coarser (up to $2 \mathrm{~mm}$ ) compared to euhedral chromite, but appears in much lower total modal quantities. Units 7-9\# contain the coarsest lobate and poikilitic chromites in the basal dunite (Fig. $4 \mathrm{c}$ and d).

The heteradcumulate unit (unit \#9 in Fig. 2 and Table 1), found along the basal dunite-layered series contact, has a distinct poikilitic texture with sparse pseudomorphic orthopyroxene grains $2-5 \mathrm{~cm}$ in diameter enclosing olivine grains (Fig. 3d), but otherwise its petrography is similar to the regular olivine adcumulates. Midway up through the unit, chromite texture changes from coarse poikilitic to more abundant fine-grained euhedral, and continues like this until the layered series contact (Fig. 2c). A relatively heterogeneous $50 \mathrm{~m}$ thick unit (unit \#10) comprising $0.5-5 \mathrm{~m}$ thick interlayers of variable-textured harzburgitic to orthopyroxenitic adcumulates and mesocumulates (Fig. 3e) is found within the heteradcumulate unit, about $100 \mathrm{~m}$ before the layered series contact. The change from poikilitic to cumulus orthopyroxene (and also chromite) observed from unit \#9 to

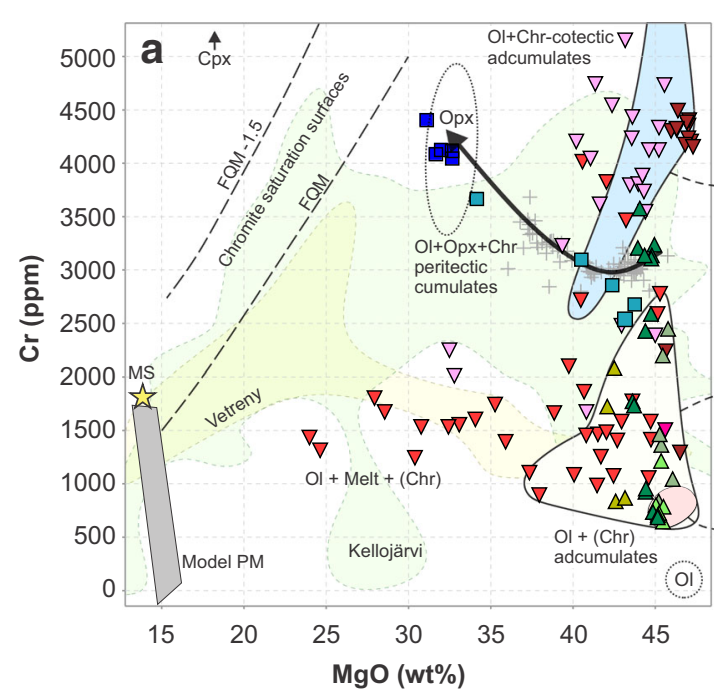

Fig. 4 a Whole-rock $\mathrm{MgO}$ versus $\mathrm{Cr}$ compositions of Näränkävaara basal dunite samples. Olivine adcumulate samples (units \#3, 4, 6, 7, 8, and 9) represent either olivine cumulates or olivine chromite cumulates, whereas the SW border zone ortho- and mesocumulate samples (units \#1, 2) represent olivine-melt mixes ( \pm chromite) (Barnes 1998). Labeled fields show (1) modeled basal dunite parental magma composition ("Model PM"), and (2) comparisons to whole-rock compositions from the

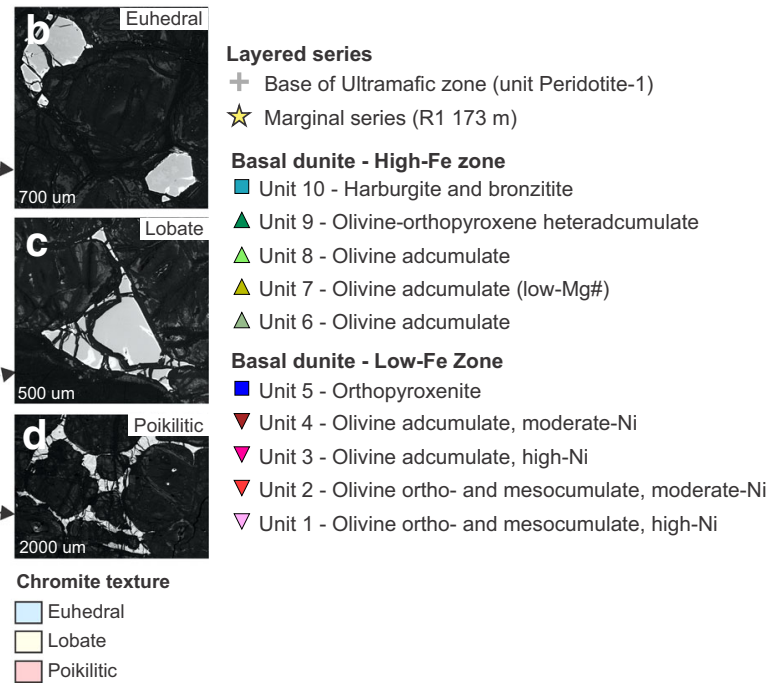

komatiitic basalts of the Vetreny Belt (Puchtel et al. 1997) and the komatiitic Kellojärvi ultramafic cumulate complex (Papunen et al. 2009). Colored fields indicate texture of chromites in thin section (see legend); b-c Back-scattered electron images of chromites with thin chromian magnetite rims, number indicates length of picture bottom edge; b lower grain euhedral, upper grain interstitial (sample JSN-87), c lobate (sample JSN-89), d poikilitic (sample VJJA-81) 
unit \#10 is in line with the common observation that poikilitic phases precede the appearance of that phase as cumulus (Campbell 1987).

A subvertical tectonized contact between the olivine heteradcumulate (unit \#9) and the Näränkävaara layered series is intersected in drill hole R1 at a depth of $\sim 170 \mathrm{~m}$. The contact includes a $10 \mathrm{~m}$ thick noncumulus textured melagabbronoritic marginal series developed on the side of the layered series (bright red in Fig. 2c) (Järvinen et al. 2020).

\section{Whole-rock chemical compositions}

\section{Main results}

Results of representative whole-rock analyses of the Näränkävaara basal dunite are presented in Table 2. All samples are MgO-rich (24-47 wt\%). Olivine adcumulates contain 45-47.7 wt\% MgO, with the exception of one low-Mg\# adcumulate unit with only $42 \mathrm{wt} \% \mathrm{MgO}$ (unit \#6 in Table 1 and Fig. 2). In the adcumulates, $\mathrm{FeO}_{\mathrm{t}}$ ranges between 9.0$13.2 \mathrm{wt} \%$, and increases with decreasing $\mathrm{MgO}$ (Mg\# 84.490.4; Fig. 5). Mesocumulates contain 39-45.5 wt\% $\mathrm{MgO}$ and orthocumulates 31-38 wt \% MgO, but values down to $24 \mathrm{wt} \%$ are found in heavily altered (olivine-pyroxenitic?) samples closest to the basement contact. The heteradcumulates in drill holes R1 and R2 (unit \#9) typically contain 42-45 wt\% MgO, grading down to $32-34 \mathrm{wt} \%$ in the orthopyroxenite interlayers (unti \#10). On Pearce element ratio plots of $(\mathrm{Mg}+\mathrm{Fe}) / \mathrm{Al}$ versus $\mathrm{Si} / \mathrm{Al}$, all olivine cumulate and heteradcumulate units plot on straight lines with slopes of 1.7-2.0. This indicates strong olivine control of whole-rock compositions as pure olivine plots on a slope of 2.0.

Based on olivine-compatible element concentrations in whole-rock samples, the basal dunite can be divided into two zones with overlapping $\mathrm{MgO}$ contents (Fig. 6a): (1) a more primitive low-Fe zone (units \#1-5; downwardtriangles in all diagrams), characterized by relatively low $\mathrm{FeO}_{\mathrm{t}}$ (average 10.2 wt\%) and high $\mathrm{Ni}$ (average $2250 \mathrm{ppm}$ ), with $\mathrm{MgO}$ between 32 and 47.3 wt\% (Mg\# 85.3-90.4); and (2) a more fractionated high-Fe zone (units \#6-10; upwardtriangles in all diagrams) characterized by relatively high $\mathrm{FeO}_{\mathrm{t}}$ (average $12.5 \mathrm{wt} \%$ ) and low $\mathrm{Ni}$ (average $1700 \mathrm{ppm}$ ), with $\mathrm{MgO}$ between 40 and 46.0 (Mg\# 85.7-88.6). The low-Fe zone can be further subdivided into a high-Ni subzone with an average of 2500 ppm Ni (units \#1 and \#3; pink in Fig. 6e and all other diagrams), and a moderate-Ni subzone (units \#2 and \#4; red in Fig. 6e and all other diagrams) with an average of $2000 \mathrm{ppm} \mathrm{Ni}$. Average $\mathrm{Al}_{2} \mathrm{O}_{3} / \mathrm{TiO}_{2}$ is slightly higher in the low-Fe zone (22) compared to the high-Fe zone (19), ranging 16-26.

As shown in Figs. 2 and 7, the low-Fe zone (units \#1-5) encompasses the ortho- and mesocumulate border zone, the lowermost olivine adcumulates, and the lowermost orthopyroxenite unit. The high-Fe zone (units \#6-10) encompasses the rest of the basal dunite up to the layered series contact. The high-Ni subzone of the low-Fe zone has only been intersected in drill holes R6, R7, and R9, and thus does not appear in the geochemical profile in Fig. 7.

The low-Fe and high-Fe zones both have variable $\mathrm{Cr}$ concentrations. Chromite texture roughly correlates with whole-rock $\mathrm{Cr}$ contents (Fig. 4): poikilitic and lobate chromite is found in high$\mathrm{MgO}$ low-Cr cumulates, and euhedral-subhedral chromite in highCr cumulates. Similar MgO-Cr systematics have been described from komatiites (Barnes and Hill 1995; Barnes 1998). In the basal dunite, highest $\mathrm{Cr}$ contents (2000-5160 ppm) are found in samples with euhedral and/or weakly interstitial chromite (Fig. 4). Lower Cr contents $(<2000 \mathrm{ppm})$ are found in samples with lobate chromite. Lowest $\mathrm{Cr}$ contents (700-850 ppm) are found in samples with poikilitic chromite, which does not appear together with euhedral chromite. Sharp changes in whole-rock $\mathrm{Cr}$ contents of about 2000 ppm are associated with a change from anhedral to more abundant euhedral-subhedral chromite (Fig. 7d).

\section{Orthocumulate and heteradcumulate compositions}

In the adcumulates, olivine-incompatible trace element contents are generally very low or below detection limits. Exception is cobalt (Table 2), which is uniformly higher in the high-Fe zone (average $140 \mathrm{ppm}$ ) compared to the low-Fe zone (average 105 ppm).

Variation diagrams in Fig. $6 \mathrm{~b}$ and d show two linear trends of increasing $\mathrm{TiO}_{2}$ and $\mathrm{Al}_{2} \mathrm{O}_{3}$ versus decreasing $\mathrm{MgO}$. The more distinctive one is related to the ortho- and mesocumulates of the border zone (units \#1-2; $\mathrm{TiO}_{2}<$ $0.41 \mathrm{wt} \%$ and $\mathrm{Al}_{2} \mathrm{O}_{3}<9.4 \mathrm{wt} \%$ ), and the less well-defined to the heteradcumulates and their harzburgitic interlayers (units \#9-10; $\mathrm{TiO}_{2}<0.08$ wt $\%$ and $\mathrm{Al}_{2} \mathrm{O}_{3}<1.2 \mathrm{wt} \%$ ). Regression lines for both trends cross the $\mathrm{x}$-axis at $\mathrm{MgO}$ values between 46 and 48 wt\%, which coincides with measured olivine compositions.

For the ortho- and mesocumulates (units \#1-2), similar compositional trends with no inflection points are almost invariably found regardless of which elements are plotted against each other (see Fig. 8a and b). This suggests that these rocks are mixtures of cumulus olivine and trapped intercumulus melt. These samples also plot along olivinemelt mixing lines in the $\mathrm{MgO}$ versus $\mathrm{Ni}$ diagram in Fig. 6e (Barnes and Fiorentini 2012), and, in respect to the moderate$\mathrm{Ni}$ subgroup (unit \#2), also in the $\mathrm{MgO}$ versus $\mathrm{Cr}$ diagram in Fig. 4 (Barnes 1998). This explanation also agrees with petrographic observations, and thus these trends are interpreted as linear olivine-melt mixing lines.

In contrast, in the olivine-orthopyroxene heteradcumulates and their interlayers (units \#9-10 in Fig. 6), incompatible elements do not notably increase with decreasing $\mathrm{MgO}$. Instead, 
Table 2 Representative results of whole-rock chemical analyses from the Näränkävaara basal dunite, with a modeled parental magma composition for the basal dunite and comparison to the Näränkävaara marginal series gabbronorite

\begin{tabular}{|c|c|c|c|c|c|c|c|c|c|c|}
\hline \multirow{2}{*}{$\begin{array}{l}\text { Zone (subzone) } \\
\text { Rocktype }^{3}\end{array}$} & \multirow{2}{*}{$\begin{array}{l}\text { Low-Fe (high-Ni) } \\
\text { Per }\end{array}$} & \multicolumn{3}{|c|}{ Low-Fe (moderate-Ni) } & \multicolumn{4}{|l|}{ High-Fe } & \multirow{2}{*}{$\begin{array}{l}\text { Marginal Series }{ }^{1} \\
\text { Mgbnor }\end{array}$} & \multirow{2}{*}{$\begin{array}{l}\text { Modeled } \\
\text { parental magma }\end{array}$} \\
\hline & & Serp & Dun & Dun & Dun & Dun & Dun & $\mathrm{Hzb}$ & & \\
\hline Cumulus $^{4}$ & oMCba? & obMCa*? & oACba? & $\mathrm{oAC}$ & $\mathrm{oAC}$ & $\mathrm{oAC}$ & $\mathrm{oMC}(\mathrm{b} *)$ & obAC( $\left(a^{*}\right)$ & abMCpf & \\
\hline Unit \# & 1 & 2 & 2 & 4 & 7 & 8 & 9 & 10 & & \\
\hline Sample $^{5}$ & 1 & 2 & 3 & 4 & 5 & 6 & 7 & 8 & 9 & \\
\hline \multicolumn{11}{|c|}{ Major oxides (wt\%) } \\
\hline $\mathrm{SiO}_{2}$ & 45.15 & 46.44 & 42.23 & 41.60 & 43.50 & 41.44 & 41.49 & 46.43 & 54.28 & 50.70 \\
\hline $\mathrm{TiO}_{2}$ & 0.14 & 0.34 & 0.03 & 0.02 & 0.01 & 0.01 & 0.01 & 0.04 & 0.52 & 0.54 \\
\hline $\mathrm{Al}_{2} \mathrm{O}_{3}$ & 2.77 & 8.29 & 0.78 & 0.34 & 0.21 & 0.16 & 0.22 & 0.65 & 11.34 & 12.24 \\
\hline $\mathrm{FeO}_{\mathrm{t}}$ & 9.85 & 9.65 & 11.49 & 9.99 & 13.46 & 12.29 & 12.46 & 11.34 & 9.42 & $9.23^{*}$ \\
\hline $\mathrm{MnO}$ & 0.14 & 0.21 & 0.17 & 0.13 & 0.20 & 0.17 & 0.18 & 0.18 & 0.17 & n.a. \\
\hline $\mathrm{MgO}$ & 41.61 & 28.83 & 45.16 & 47.69 & 42.58 & 45.49 & 45.13 & 40.49 & 13.79 & 15.59 \\
\hline $\mathrm{CaO}$ & 0.14 & 5.99 & 0.10 & 0.20 & 0.05 & 0.44 & 0.45 & 0.86 & 7.20 & 8.82 \\
\hline $\mathrm{Na}_{2} \mathrm{O}$ & 0.08 & 0.07 & $<0.03$ & $<0.03$ & $<0.03$ & $<0.03$ & 0.05 & $<0.03$ & 2.33 & 0.10 \\
\hline $\mathrm{K}_{2} \mathrm{O}$ & 0.09 & 0.11 & 0.04 & 0.01 & $<0.003$ & $<0.003$ & 0.01 & 0.01 & 0.84 & 0.80 \\
\hline $\mathrm{P}_{2} \mathrm{O}_{5}$ & 0.02 & 0.07 & 0.01 & 0.01 & $<0.006$ & 0.01 & $<0.006$ & $<0.006$ & 0.10 & n.a. \\
\hline \multicolumn{11}{|c|}{ Trace elements (ppm) } \\
\hline $\mathrm{Cl}$ & 900 & 200 & 2600 & 1500 & 606 & 900 & 2400 & 1400 & 2300 & n.a. \\
\hline $\mathrm{Cr}$ & 3620 & 1670 & 1050 & 4210 & 831 & 780.00 & 680 & 3100 & 1820 & 1696 \\
\hline $\mathrm{Cu}$ & 20 & 20 & $<20$ & $<20$ & $<20$ & $<20$ & $<20$ & $<20$ & 70 & n.a. \\
\hline $\mathrm{Ni}$ & 2460 & 1220 & 2100 & 2330 & 2023 & 1630.0 & 1610 & 1120 & 530 & 702 \\
\hline $\mathrm{S}$ & 1300 & 400 & 200 & 200 & $<100$ & $<100$ & $<100$ & $<100$ & 600 & n.a. \\
\hline $\mathrm{Sr}$ & 20 & 50 & $<10$ & $<10$ & $<10$ & $<10$ & 20 & 20 & 210 & n.a. \\
\hline $\mathrm{V}$ & 30 & 90 & 20 & 20 & $<10$ & 10.00 & 10 & 30 & 140 & n.a. \\
\hline $\mathrm{Zr}$ & 10 & 40 & $<10$ & $<10$ & $<10$ & $<10$ & $<10$ & $<10$ & 80 & n.a. \\
\hline $\mathrm{La}$ & n.a. & 6.74 & n.a. & n.a. & n.a. & 0.19 & $<0.1$ & n.a. & 12.20 & 9.85 \\
\hline $\mathrm{Ce}$ & n.a. & 13.90 & n.a. & n.a. & n.a. & 0.23 & $<0.1$ & n.a. & 24.40 & 20.62 \\
\hline $\operatorname{Pr}$ & n.a. & 1.65 & n.a. & n.a. & n.a. & $<0.1$ & $<0.04$ & n.a. & 2.83 & 2.57 \\
\hline $\mathrm{Nd}$ & n.a. & 6.81 & n.a. & n.a. & n.a. & $<0.2$ & $<0.2$ & n.a. & 11.70 & 10.52 \\
\hline $\mathrm{Sm}$ & n.a. & 1.50 & n.a. & n.a. & n.a. & $<0.2$ & $<0.06$ & n.a. & 2.37 & 2.38 \\
\hline $\mathrm{Eu}$ & n.a. & 0.32 & n.a. & n.a. & n.a. & $<0.1$ & $<0.03$ & n.a. & 0.67 & 0.48 \\
\hline $\mathrm{Gd}$ & n.a. & 1.55 & n.a. & n.a. & n.a. & $<0.2$ & $<0.09$ & n.a. & 2.40 & 2.39 \\
\hline $\mathrm{Tb}$ & n.a. & 0.24 & n.a. & n.a. & n.a. & $<0.1$ & $<0.04$ & n.a. & 0.37 & 0.35 \\
\hline Dy & n.a. & 1.43 & n.a. & n.a. & n.a. & $<0.1$ & $<0.06$ & n.a. & 2.29 & 2.31 \\
\hline Ho & n.a. & 0.29 & n.a. & n.a. & n.a. & $<0.1$ & $<0.04$ & n.a. & 0.48 & 0.48 \\
\hline $\mathrm{Er}$ & n.a. & 0.84 & n.a. & n.a. & n.a. & $<0.2$ & $<0.04$ & n.a. & 1.44 & 1.36 \\
\hline $\mathrm{Tm}$ & n.a. & 0.12 & n.a. & n.a. & n.a. & $<0.1$ & $<0.03$ & n.a. & 0.20 & 0.15 \\
\hline $\mathrm{Yb}$ & n.a. & 0.77 & n.a. & n.a. & n.a. & $<0.2$ & 0.04 & n.a. & 1.36 & 1.20 \\
\hline $\mathrm{Lu}$ & n.a. & 0.11 & n.a. & n.a. & n.a. & $<0.1$ & $<0.03$ & n.a. & 0.20 & 0.12 \\
\hline Hf & n.a. & 1.21 & n.a. & n.a. & n.a. & 2.06 & $<0.5$ & n.a. & 1.55 & n.a. \\
\hline $\mathrm{Zr}$ & n.a. & 40 & n.a. & n.a. & n.a. & 3.00 & 6 & n.a. & 60 & 58 \\
\hline $\mathrm{Y}$ & n.a. & 7.63 & n.a. & n.a. & n.a. & $<0.2$ & 0.20 & n.a. & 11.80 & 9.62 \\
\hline $\mathrm{Nb}$ & n.a. & $<3$ & n.a. & n.a. & n.a. & $<0.2$ & $<3$ & n.a. & $<3$ & n.a. \\
\hline $\mathrm{Ta}$ & n.a. & $<1$ & n.a. & n.a. & n.a. & $<0.2$ & $<1$ & n.a. & $<1$ & n.a. \\
\hline $\mathrm{Rb}$ & n.a. & 5.50 & n.a. & n.a. & n.a. & 0.29 & $<0.8$ & n.a. & 29.60 & 25.16 \\
\hline $\mathrm{Th}$ & n.a. & $<2$ & n.a. & n.a. & n.a. & 1.27 & $<2$ & n.a. & 3.40 & n.a. \\
\hline $\mathrm{U}$ & n.a. & 0.50 & n.a. & n.a. & n.a. & $<0.2$ & $<0.06$ & n.a. & 0.75 & n.a. \\
\hline $\mathrm{Sc}$ & n.a. & 14.2 & n.a. & n.a. & n.a. & 3.30 & 4.1 & n.a. & 23.8 & 21.9 \\
\hline
\end{tabular}


Table 2 (continued)

\begin{tabular}{|c|c|c|c|c|c|c|c|c|c|c|}
\hline \multirow{2}{*}{$\begin{array}{l}\text { Zone (subzone) } \\
\text { Rocktype }^{3}\end{array}$} & \multirow{2}{*}{$\begin{array}{l}\text { Low-Fe (high-Ni) } \\
\text { Per }\end{array}$} & \multicolumn{3}{|c|}{ Low-Fe (moderate-Ni) } & \multicolumn{4}{|c|}{ High-Fe } & \multirow{2}{*}{$\begin{array}{l}\text { Marginal Series }{ }^{1} \\
\text { Mgbnor }\end{array}$} & \multirow{2}{*}{$\begin{array}{l}\text { Modeled } \\
\text { parental magma }\end{array}$} \\
\hline & & Serp & Dun & Dun & Dun & Dun & Dun & $\mathrm{Hzb}$ & & \\
\hline $\mathrm{V}$ & n.a. & 89.9 & n.a. & n.a. & n.a. & 7.40 & 9.2 & n.a. & 150.0 & 151.1 \\
\hline Co & n.a. & 91.5 & n.a. & n.a. & n.a. & 140.00 & 138.0 & n.a. & 58.0 & 78.9 \\
\hline $\mathrm{Au}(\mathrm{ppb})$ & $<1$ & $<1$ & $<1$ & $<1$ & $<1$ & $<1$ & $<1$ & $<1$ & 2.40 & n.a. \\
\hline $\mathrm{Pd}(\mathrm{ppb})$ & $<1$ & 1.30 & $<1$ & $<1$ & $<1$ & 1.00 & $<1$ & $<1$ & 6.70 & n.a. \\
\hline $\mathrm{Pt}(\mathrm{ppb})$ & $<1$ & 4.50 & $<1$ & $<1$ & $<1$ & $<1$ & $<1$ & $<1$ & 8.60 & n.a. \\
\hline
\end{tabular}

Elements from $\mathrm{SiO}_{2}$ to $\mathrm{Zr}$ analyzed with XRF; from La to Co with ICP-MS; from Au to Pt with $\mathrm{GFAAS}$; $\mathrm{FeO}_{\mathrm{t}}=$ total $\mathrm{FeO}$

${ }^{1}$ Marginal series gabbronorite composition from Järvinen et al. (2020)

${ }^{2}$ Average of model results from units \#1-2 (Cr from unit \#1 only) with model parameters $\mathrm{Fo}_{90-91}$ and $\mathrm{K}_{\mathrm{D}} 0.30-0.33$ (see text), ${ }^{*}$ iron is $\mathrm{FeO}$ not $\mathrm{FeO}$ total

${ }^{3}$ Dunite $=$ Dun Peridotite $=$ Per $;$ Harzburgite $=H z b ;$ Serpentinite $=$ Serp $;$ Melagabbronorite $=$ Mgbnor

${ }^{4}$ Cumulus nomenclature after Irvine (1982), with the exceptions that intercumulus phases marked as suffix, minerals $<5$ vol\% mode marked with parentheses, poikilitic phase marked with asterisk

${ }^{5}$ Samples (drill hole and depth): 1) R7 46.7 m; 2) R8 181.75 m; 3) R5 185.4 m; 4) R4 47.5 m; 5) JSN-88 (surface); 6) VJJA-68 (surface); 7 ) R2 237.9 m; 8) R2 30.4 m; 9) R1 173.65 m

the trend lines coincide with measured olivine and orthopyroxene compositions, and these units can be modeled as linear mixtures of olivine and orthopyroxene. They are thus interpreted as heteradcumulates with no (or only minor) trapped intercumulus melt (e.g. Barnes et al. 2016b).

\section{Rare earth element compositions}

Chondrite-normalized REE and primitive-mantlenormalized trace element patterns for the basal dunite samples are presented in Fig. 9. All adcumulates and heteradcumulates (units \#3-10) are very REE-poor, with La between 0.5-1 times chondritic and most HREE below detection limits. The border zone ortho- and mesocumulates (units \#1-2) are LREE-enriched with Lavalues approximately 2-20 times chondritic. Negative $\mathrm{Eu}$ and $\mathrm{Sr}$ anomalies are likely related to Ca-mobility during serpentinization. Total REE-abundances increase with decreasing $\mathrm{MgO}$, which together with the parallel REEpatterns suggests olivine control (dilution) of REE. The REE patterns are interpreted to mainly reflect the amount and composition of the trapped intercumulus melt.

\section{Chalcophile elements}

Concentrations of chalcophile elements are generally low in the basal dunite, except for $\mathrm{Ni}$, which must be almost entirely hosted by olivine judging from the overall low concentrations of sulfur (Table 2). In the adcumulates and heteradcumulates (units \#3-10), $\mathrm{Cu}, \mathrm{Pd}, \mathrm{Pt}$, and $\mathrm{S}$ are mostly below detection limits. The border zone cumulates (units \#1-2) contain on average 480 ppm S (highest 1300 ppm). Most $\mathrm{Cu}$ and about half of Pd and Pt analysis results are below detection limits; highest measured $\mathrm{Cu}$ is $170 \mathrm{ppm}, \mathrm{Pd}$ is $5.7 \mathrm{ppb}$, and $\mathrm{Pt}$ is $10.8 \mathrm{ppb}$.

\section{Mineral chemistry}

\section{Chromite}

Results of representative EPMA mineral analyses are listed in Table 3. All analyzed spinels from the basal dunite (39 samples, 119 grains, 453 analyses) are classified as chromites after the most abundant trivalent ion (Fig. 10), except for two samples that contain three grains classified as spinels. Chromites have compositions with (average in parentheses): $\mathrm{Mg} \# 0.12-0.5$ (0.32), Cr\# $0.45-0.80(0.63), \mathrm{Fe}^{3+} \# 0.03-0.51$ (0.12), NiO $0.03-$ $0.22 \mathrm{wt} \%(0.1 \mathrm{wt} \%)$, and $\mathrm{ZnO} 0.08-1.43 \mathrm{wt} \%$ $(0.4 \mathrm{wt} \%)$ where $\mathrm{Cr} \#=\mathrm{Cr} /(\mathrm{Cr}+\mathrm{Al})$ and $\mathrm{Fe}^{3+} \#=\mathrm{Fe}^{3+} /$ $\left.\left(\mathrm{Cr}+\mathrm{Al}+\mathrm{Fe}^{3+}\right)\right]$. There is large overlap in compositions, but generally the ortho- and mesocumulates (units \#1-2) contain more chromian and ferrian chromites, while the adcumulates (units \#3-10) contain more aluminian chromites (Fig. 10). Chromite core compositions are igneous based on constraints of Barnes and Roeder (2001). Chromite compositions overlap with the compositional fields of both layered intrusions and komatiites (Fig. 10) (Barnes and Roeder 2001). No systematic compositional variations between euhedral and lobate-poikilitic chromite grains were found.

Chromites from ortho- and mesocumulates (units \#12) exhibit a wider range of $\mathrm{Fe}_{2} \mathrm{O}_{3}$ compositions (5$21.5 \mathrm{wt} \%$ ) compared to those from other units (average $5.8 \mathrm{wt} \%$ ) (Fig. 10a and c). In back-scattered electron (BSE) imaging, the chromites do not exhibit magmatic 


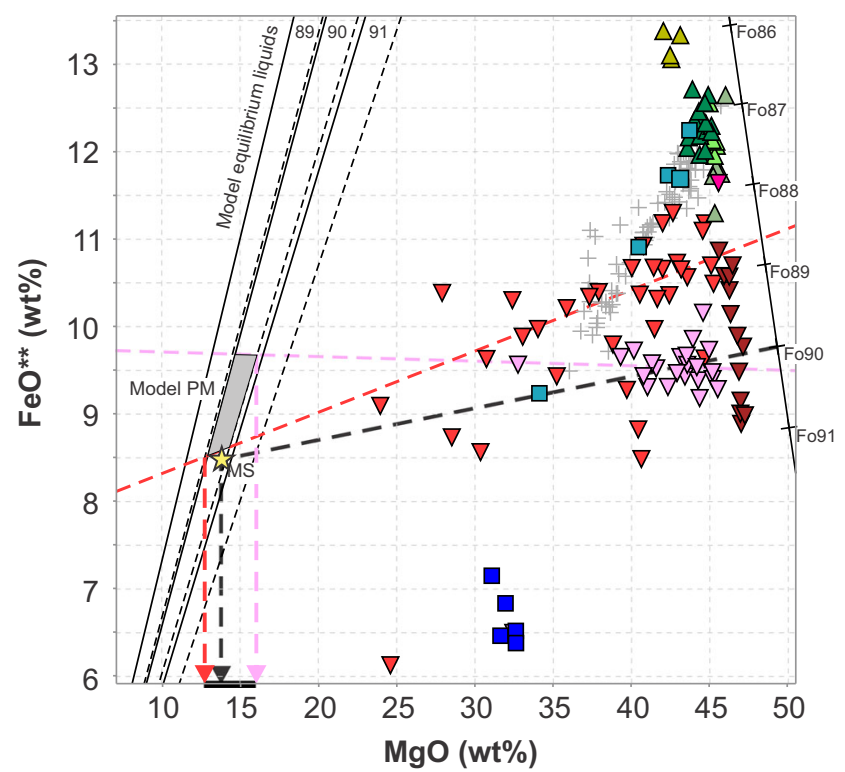

Layered series

+ Base of Ultramafic zone (unit Peridotite-1)

岤 Marginal series (R1 $173 \mathrm{~m})$

Basal dunite - High-Fe zone

$\square$ Unit 10 - Harburgite and bronzitite

$\triangle$ Unit 9 - Olivine-orthopyroxene heteradcumulate

$\triangle$ Unit 8 - Olivine adcumulate

$\triangle$ Unit 7 - Olivine adcumulate (low-Mg\#)

$\triangle$ Unit 6 - Olivine adcumulate

Basal dunite - Low-Fe Zone

- Unit 5 - Orthopyroxenite

$\nabla$ Unit 4 - Olivine adcumulate, moderate-Ni

$\nabla$ Unit 3 - Olivine adcumulate, high-Ni

$\nabla$ Unit 2 - Olivine ortho- and mesocumulate, moderate-Ni

$\nabla$ Unit 1 - Olivine ortho- and mesocumulate, high-Ni

Fig. 5 Whole-rock $\mathrm{MgO}$ versus $\mathrm{FeO} * *$ compositions of Näränkävaara basal dunite samples; $\mathrm{FeO}^{* *}$ is $\mathrm{FeO}$ calculated from total $\mathrm{FeO}$ according to Barnes et al. (2007). Pure olivine compositions $\mathrm{Fo}_{86-91}$ are plotted on the right, and model liquids in equilibrium with $\mathrm{Fo}_{89-91}$ olivines with olivine-liquid Fe-Mg exchange coefficient $\left(\mathrm{K}_{\mathrm{D}}\right)$ values of 0.30 (solid black lines) and 0.33 (dashed black lines) (Roeder and Emslie 1970) are plotted on the left. Figure illustrates modeling of the Näränkävaara basal dunite parental magma composition: Units \#1 and \#2 are interpreted to be composed of olivine-melt mixtures; regression lines fitted through these units (dashed pink line for unit\#1 and red for unit \#2) intersect with $\mathrm{Fo}_{90}$ equilibrium liquid compositions with $\mathrm{K}_{\mathrm{D}} 0.30-0.33$ at $13-16.1 \mathrm{wt} \%$ $\mathrm{MgO}$ (black bar on X-axis). Field labeled "Model PM" shows the range of modeled parental magma compositions that results for units \#1 and \#2 using a liquid composition in equilibrium with $\mathrm{Fo}_{90}$ olivine at $\mathrm{K}_{\mathrm{D}}$ values 0.30 and 0.33 ; note that this field has been plotted in all other variation diagrams in this paper. Black dashed line connects compositions of olivine and liquid in equilibrium with the Näränkävaara marginal series gabbronorite composition (Järvinen et al. 2020)

zoning, but thin chromian magnetite rims with $\mathrm{Fe}_{2} \mathrm{O}_{3}$ replacing $\mathrm{Al}_{2} \mathrm{O}_{3}$ are commonly found (Fig. $4 \mathrm{~b}-\mathrm{d}$ ) especially in the orthocumulate samples. The orthocumulate chromites also have higher contents of e.g. Mn, V, Zn, and $\mathrm{Ni}$, with abundances of these elements increasing with decreasing whole-rock MgO. Barnes (1998) interpreted similar compositional trends in komatiitic cumulates as post-cumulus equilibration between chromite and trapped intercumulus melt during slow cooling. Compositional variations in chromites along the $\mathrm{X}-\mathrm{X}$ ' cross-section (Fig. 2) are illustrated in Fig. S2.

\section{Olivine}

Fresh olivine in the Näränkävaara basal dunite was found in only 13 samples. Relatively abundant fresh olivine is found in some less-altered ortho- and mesocumulate samples (units\# 1-2), and also in the (olivine) orthopyroxenites (units \#5 and 10). In the adcumulates and heteradcumulates olivine has only been found in two samples as small relict cores in otherwise serpentinized pseudomorphs (units \#8-9).

The analyzed olivine compositions range between $\mathrm{Fo}_{87-88.6}$, with two orthocumulate samples extending down to $\mathrm{Fo}_{84.5}$ (see Tables 1 and 3). Highest measured forsterite content of $\mathrm{Fo}_{88.6}$ is from an olivine mesocumulate boulder (unit \#1); the second highest of $\mathrm{Fo}_{88.5}$ is found in the lowermost orthopyroxenite (unit \#5). Analyzed olivines exhibit three different levels of $\mathrm{Ni}$ concentrations (Fig. 11): (1) high-Ni from 0.40 $0.37 \mathrm{wt} \% \mathrm{NiO}$; (2) moderate-Ni from $0.30-0.28 \mathrm{wt} \%$ $\mathrm{NiO}$; and (3) low-Ni from $0.28-0.21 \mathrm{wt} \% \mathrm{NiO}$. These levels mirror whole-rock $\mathrm{Ni}$ values and the geochemical subdivision presented earlier (Fig. 6e). Compared to a statistical analysis of komatiitic olivine compositions by Barnes and Fiorentini (2012), the Ni-richest olivines from the low-Fe zone (unit \#1) can be classified as both" mineralized komatiites" and "barren units in mineralized domains", while all other olivine analysis results fall in the field of "fresh olivine in unmineralized komatiites".

\section{Pyroxenes}

Orthopyroxene was analyzed from nine samples and clinopyroxene from seven samples (Table 3 ). Orthopyroxene compositions range between $\mathrm{En}_{83.7-87.0}$, $\mathrm{Fs}_{9.7-12.2}$, and $\mathrm{Wo}_{2.4-4.5}$; with $\mathrm{Cr}_{2} \mathrm{O}_{3}$ between $0.5-0.7$ wt\% and $\mathrm{NiO}$ between $0.05-0.11 \mathrm{wt} \%$. Clinopyroxenes range between $\mathrm{En}_{46.7-52.1}, \mathrm{Fs}_{5.8-7.2}$, and $\mathrm{Wo}_{39.5-44.9}$; with $\mathrm{Cr}_{2} \mathrm{O}_{3}$ between $0.65-1.30$ wt $\%$ and $\mathrm{NiO}$ between 0.03 $0.06 \mathrm{wt} \%$. Pyroxenes from the low-Fe zone contain uniformly higher $\mathrm{NiO}$ compared to those of the high-Fe zone (e.g. average of 0.048 versus $0.035 \mathrm{wt} \% \mathrm{NiO}$ in clinopyroxene). 

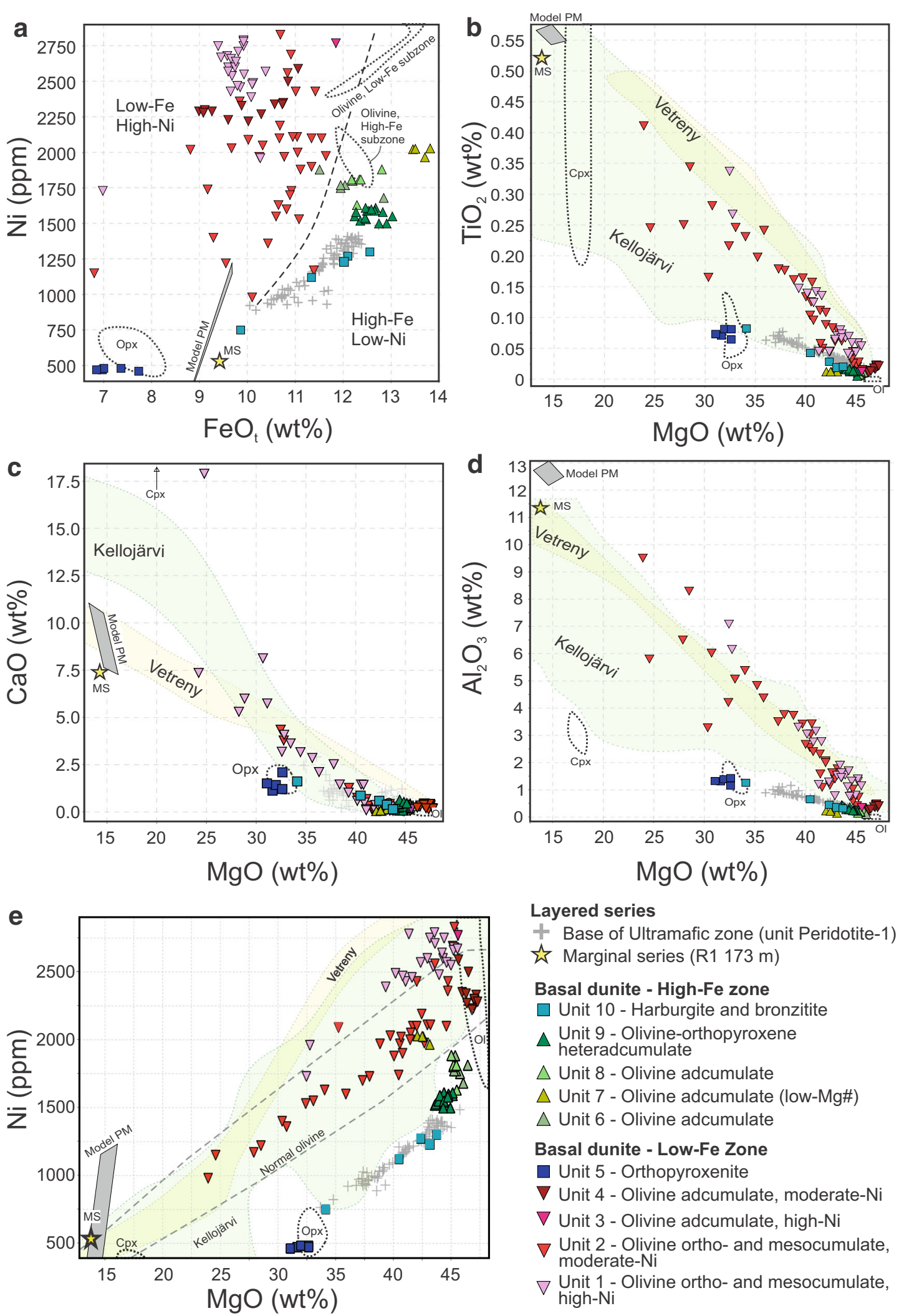

\section{Layered series}

+ Base of Ultramafic zone (unit Peridotite-1)

Therginal series (R1 $173 \mathrm{~m})$

Basal dunite - High-Fe zone

$\square$ Unit 10 - Harburgite and bronzitite

$\triangle$ Unit 9 - Olivine-orthopyroxene

heteradcumulate

$\triangle$ Unit 8 - Olivine adcumulate

$\triangle$ Unit 7 - Olivine adcumulate (low-Mg\#)

$\triangle$ Unit 6 - Olivine adcumulate

Basal dunite - Low-Fe Zone

$\square$ Unit 5 - Orthopyroxenite

$\nabla$ Unit 4 - Olivine adcumulate, moderate-Ni

$\nabla$ Unit 3 - Olivine adcumulate, high-Ni

$\nabla$ Unit 2 - Olivine ortho- and mesocumulate, moderate- $\mathrm{Ni}$

$\nabla \begin{aligned} & \text { Unit } 1 \text {-O Olivine ortho- and mesocumulate, } \\ & \text { high-Ni }\end{aligned}$

Fig. 6 a-e Whole-rock compositions of Näränkävaara basal dunite samples on variation diagrams; a Dashed line shows the main geochemical division of basal dunite samples into low-Fe and high-Fe zones. Field labeled "Model PM" shows the range of modeled basal dunite parental magma compositions. Note that the trend of the border zone ortho- and mesocumulate samples (units \#1-2) coincides with the marginal series gabbronorite of the layered series (labeled "MS"), suggesting these rocks are mixtures of cumulus olivine and melt approximately of the marginal series composition. Other labeled fields show measured mineral compositions ( $\mathrm{Ol}, \mathrm{Opx}, \mathrm{Cpx})$ and comparisons to whole-rock compositions from the komatiitic basalts of the Vetreny Belt (Puchtel et al. 1997) and the komatiitic Kellojärvi ultramafic cumulate complex (Papunen et al. 2009) 


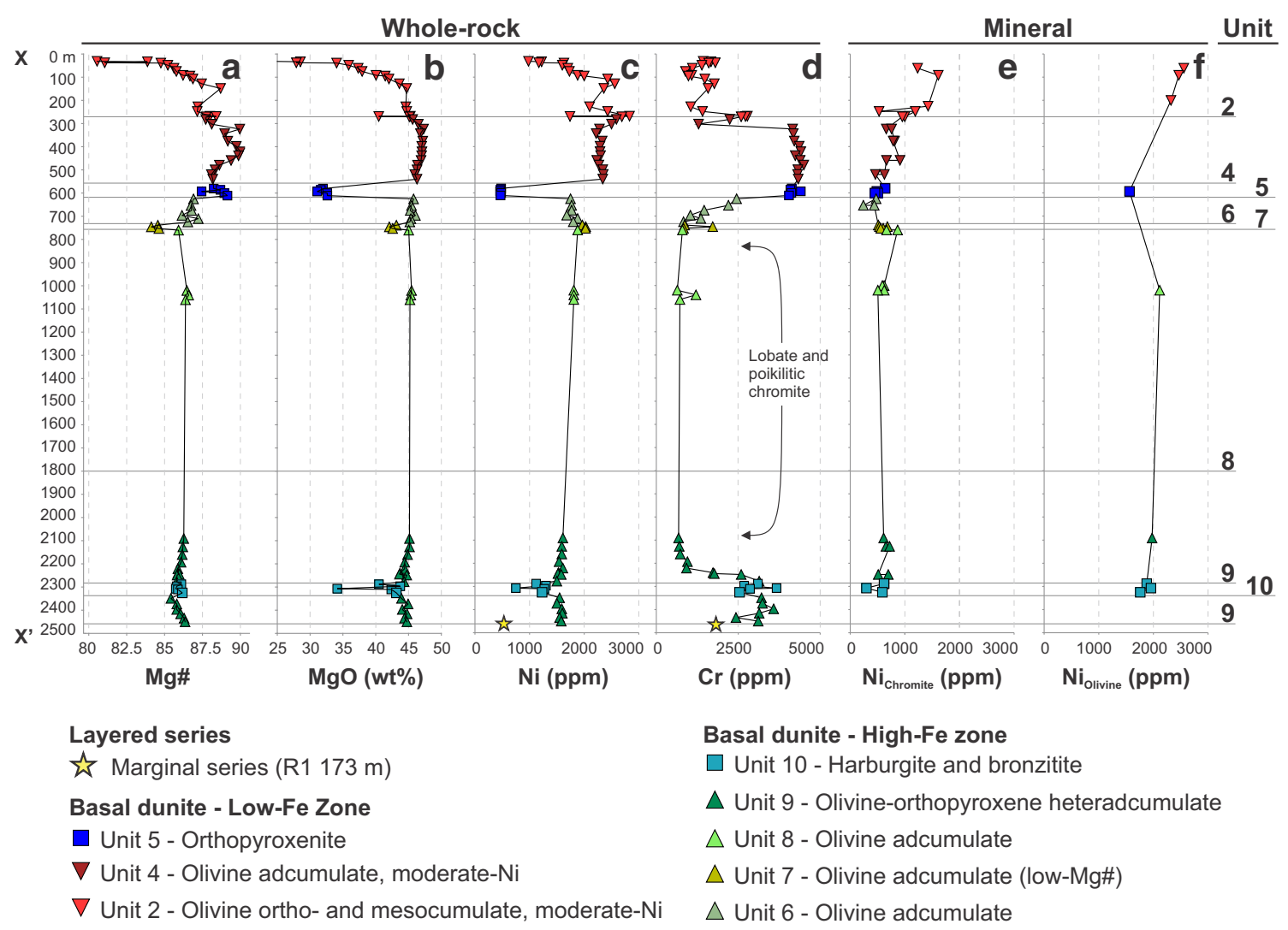

Fig. 7 a-d Whole-rock and e-f mineral chemical variations with height $(\mathrm{m})$ in the X-X' cross section in the SE block of the Näränkävaara intrusion in Fig. 2, with $0 \mathrm{~m}$ marking the $\mathrm{SW}$ contact between the basement complex and the basal dunite. Horizontal lines show unit division according to Table 1

\section{Discussion}

\section{General remarks}

Two major research questions concern the Näränkävaara basal dunite. First is related to its age and relationship with the neighboring layered series. In the SE-block of the Näränkävaara intrusion, a marginal series gabbronorite separates the dunite from the layered series (Fig. 2). Unless the current structural configuration is fully the result of postemplacement faulting, this means there has to be an age difference between the two. The basal dunite could either be (1) comagmatic with the Fennoscandian 2.5-2.4 Ga layered series magmatism, with a long enough hiatus in magmatism to allow for the cooling needed for the subsequent formation of the marginal series, or (2) represent an Archean komatiitic wall-rock to the Proterozoic layered series magmatism. Since isotope dating methods have thus far proven unsuccessful, here we aim to constrain the petrogenesis of the basal dunite by studying its parental magma composition and differentiation, and compare our findings to the neighboring layered series and to nearby komatiites. The second major research question is related to the orthomagmatic Ni-potential of the basal dunite as, in any event, it must have formed from a large volume of mantle derived primitive magma(s). Some observations related to the Ni-potential of the basal dunite are discussed at the end of this section.

\section{Parental magma}

One way to study a possible comagmatic relationship between the Näränkävaara basal dunite and the layered series is to compare their parental magma compositions. The Näränkävaara layered series parental magma has been inferred from a marginal series gabbronorite intersected in drill hole R1 (Fig. 2) (Järvinen et al. 2020). As the composition of the basal dunite parental magma cannot be directly inferred from a chilled margin or spinifex textured rock, instead the parental magma composition has been modeled here using results of whole-rock analyses from orthocumulates. The methods used here have been outlined in detail by e.g. Bickle (1982) and Chai and Naldrett (1992), and are based on the assumption that olivine orthocumulate rocks are a mixture of cumulus olivine and melt in equilibrium with this olivine. First, the Mg\# of a melt in equilibrium with the most primitive olivine found in the basal dunite was calculated by using the olivine-melt $\mathrm{Mg}$ - $\mathrm{Fe}$ exchange coefficient $\left(\mathrm{K}_{\mathrm{D}}\right)$ of Roeder and Emslie (1970). Then, the $\mathrm{MgO}$ and $\mathrm{FeO}$ contents of the parental magma were calculated from the intersection 

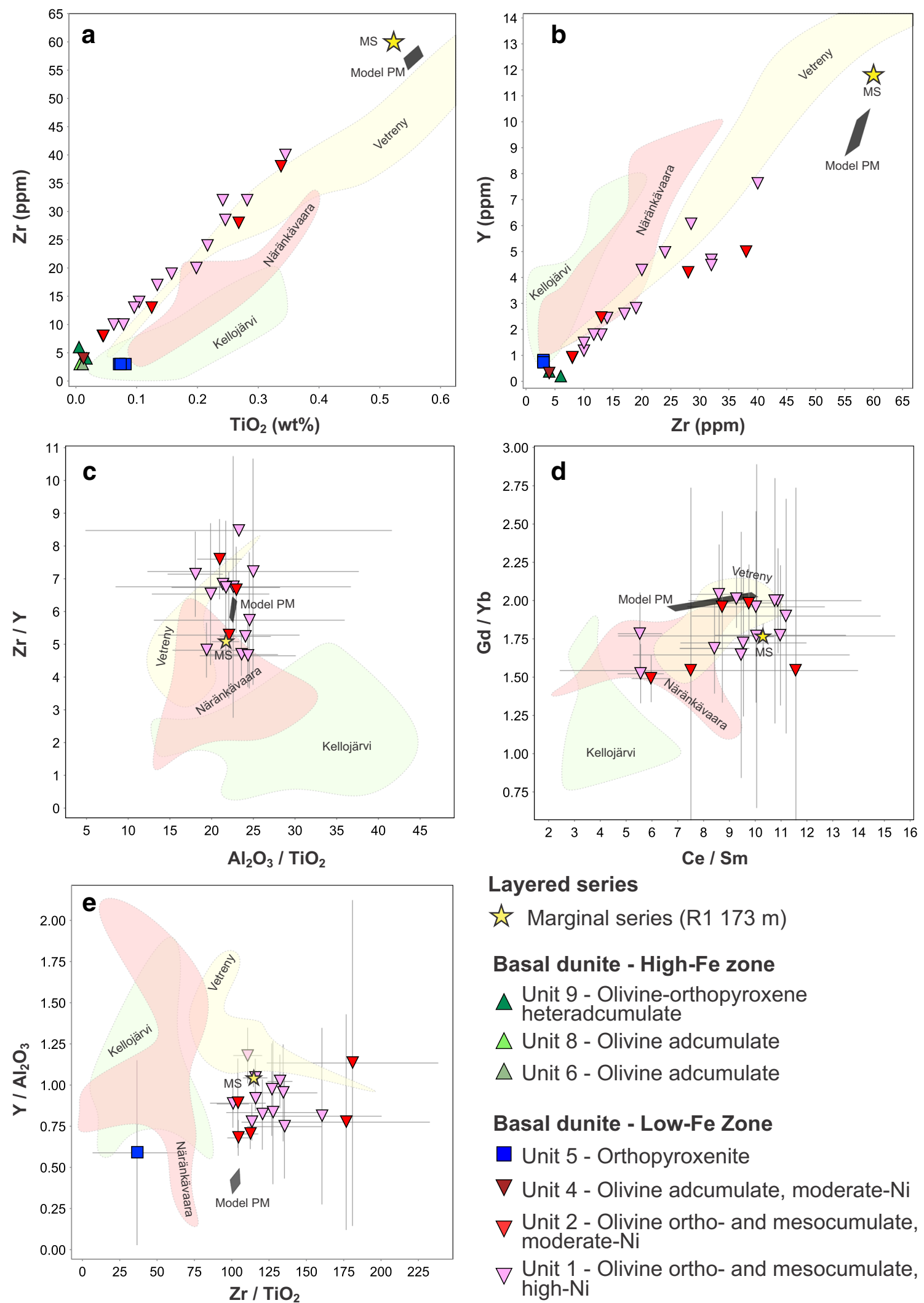

\section{Layered series}

岤 Marginal series (R1 $173 \mathrm{~m})$

\section{Basal dunite - High-Fe zone}

Unit 9 - Olivine-orthopyroxene heteradcumulate

$\triangle$ Unit 8 - Olivine adcumulate

$\triangle$ Unit 6 - Olivine adcumulate

\section{Basal dunite - Low-Fe Zone}

\section{Unit 5 - Orthopyroxenite}

$\nabla$ Unit 4 - Olivine adcumulate, moderate- $\mathrm{Ni}$

$\nabla$ Unit 2 - Olivine ortho- and mesocumulate, moderate-Ni

$\nabla$ Unit 1 - Olivine ortho- and mesocumulate, high-Ni

Fig. 8 a-e Whole-rock trace element compositions and ratios of basal dunite samples. Field labeled "Model PM" shows the range of modeled basal dunite parental magma compositions; other labeled fields show comparisons to whole-rock compositions from the Näränkävaara layered series (Järvinen et al. 2020), komatiitic basalts of the Vetreny Belt

(Puchtel et al. 1997), and the komatiitic Kellojärvi ultramafic cumulate complex (Papunen et al. 2009). Error bars show $1 \sigma$ relative errors for element ratios, samples with $1 \sigma$ errors larger than the ratio have been omitted 

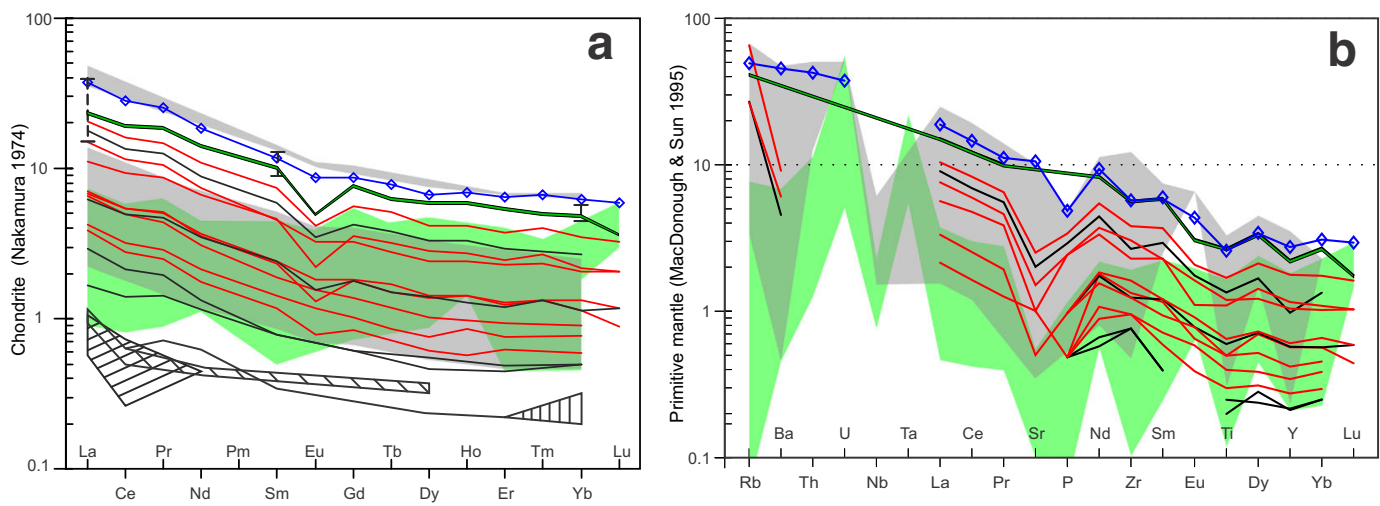

Basal dunite - Border zone ortho- and mesocumulates

- Unit 1 , high-Ni

- Unit 2, moderate-Ni

Basal dunite - Adcumulate zone

Orthopyroxenite (Unit 5)

$\exists$ Adcumulate (Units 6, 8, 9)

[1] Heteradcumulate (Unit 9)

Possible parental magmas

- Modeled parental magma

$\diamond$ Marginal series (R1 $173 \mathrm{~m}$ )

Comparisons

Kellojärvi komatiite complex

Vetreny belt
Fig. 9 a Chondrite-normalized whole-rock REE-diagram and b primitive-mantle-normalized trace element diagram for Näränkävaara basal dunite samples; normalization values from Nakamura (1974) and McDonough and Sun (1995), respectively. Also plotted is the average modeled basal dunite parental magma composition, for which vertical bars in a (for $\mathrm{La}, \mathrm{Sm}, \mathrm{Yb}$ ) show variation in model results based on regression of either unit \#1 (high-Ni) or unit \#2 (moderate-Ni) samples; note the similarity of modeled parental magma to the Näränkävaara marginal series gabbronorite. Grey and green filled fields show comparisons to whole-rock compositions from komatiitic basalts of the Vetreny Belt (Kirichi and Vinela localities from Puchtel et al. 1997), and the komatiitic Kellojärvi ultramafic cumulate complex (Papunen et al. 2009) between this equilibrium-melt composition and a regression line fitted through samples composed of olivine-melt mixtures, as illustrated in Fig. 5. As the border zone ortho- and mesocumulates (units \#1-2) are interpreted to represent olivine-melt mixtures, they were used for calculating these regression lines. Concentrations of other elements in the parental magma were then estimated in a similar fashion, by fitting regression lines through the ortho- and mesocumulate units and calculating the value of each element at the previously obtained $\mathrm{MgO}$ value. Samples taken from immediate contacts with basement or xenoliths were omitted from modeling to reduce scatter in whole-rock sample regression lines, as these near-contact samples show distinctly stronger LREE-enrichment indicative of insitu contamination (not shown).

The most primitive olivines ( $\mathrm{Fo}_{88-88.6}$ ) are found in the olivine ortho- and mesocumulates of the low-Fe zone (units \#1-2). During post-cumulus processes, olivine compositions tend to progressively re-equilibrate towards lower Fo contents as modal intercumulus increases (e.g. unit \#2 in Fig. 11) (Barnes 1986). It is thus unlikely that the olivines analyzed from the relatively intercumulus-rich ortho- and mesocumulates represent original compositions. It is also possible that the most primitive olivines have simply been destroyed during serpentinization. Therefore, average olivine compositions have also been inferred from whole-rock compositions. For the adcumulate units, olivine Fo contents can be directly inferred from whole-rock Mg\#. The highest whole-rock Mg\# of 90.4 is found in the lowermost olivine adcumulates of the low-Fe zone (unit \#4 in Fig. 7a and Table 1). A slightly higher Fo content can be inferred from the $\mathrm{MgO}$ versus $\mathrm{FeO}$ plot in Fig. 5, where these samples plot close to pure $\mathrm{Fo}_{91}$ olivine. In addition, average Fo contents were inferred from molecular ratios of whole-rock $\mathrm{Mg} / \mathrm{Al}$ and $\mathrm{Fe}^{2+} / \mathrm{Al}$ (see Makkonen et al. 2017), with results listed in Table 1. Using this latter method, results for the high-Ni subzone (unit \#1) are between $\mathrm{Fo}_{89-90}$ and for the moderate-Ni subzone (unit \#2) between $\mathrm{Fo}_{87-89}$, depending on the drill hole. Results of this method indicate similar olivine Fo contents as regression lines on variation diagrams intersecting pure model olivine compositions (e.g. Figure 5), with the added benefit of the method also being applicable to intercumulus-poor olivine adcumulate units. The most primitive olivine inferred from the basal dunite is thus in the range $\mathrm{Fo}_{90-91}$.

Parental magma compositions have been modeled separately for the high-Ni and moderate-Ni ortho- and mesocumulates (units \#1-2) with a liquid composition in equilibrium with Fo ${ }_{90-91}$, using a $\mathrm{K}_{\mathrm{D}}$ of 0.30 and 0.33 (Roeder and Emslie 1970; Toplis 2005). Resulting parental magma $\mathrm{MgO}$ varies between 13 and $18 \mathrm{wt} \%$ (average $15.6 \mathrm{wt} \%$ ), depending on the unit used for regression and the parameters used to calculate the equilibrium liquid (Fig. 5 and Table 1). The high-Ni ortho- and mesocumulates (unit \#1 in Table 1) always result in a higher parental magma $\mathrm{MgO}$ estimate compared to the moderate-Ni ortho- and mesocumulates (unit \#2 in Table 1). This difference is related to the slopes of trend lines on the $\mathrm{MgO}-\mathrm{FeO}$ diagram in Fig. 5, with unit \#1 having slightly increasing $\mathrm{FeO}$ with decreasing $\mathrm{MgO}$ resulting in a higher $\mathrm{MgO}$ intercept. As the high-Ni subzone is Ni-richer and also appears to contain slightly more forsteritic olivine (Table 1), it is plausible that it has formed from a slightly more primitive magma compared to the moderate-Ni subzone. An "average" parental magma composition for these two units has been modeled using a $\mathrm{Fo}_{90}$ equilibrium liquid and $\mathrm{K}_{\mathrm{D}}$ of both 0.30 and 0.33 (see Fig. 5) - the four resulting parental magma compositions are plotted as the corners of the "Model PM" field in variation diagrams in Figs. 4, 5, 6 and 8; with REE and trace element diagrams in Figs. 8 and 9. An average model parental magma composition is also listed in Table 2.

Overall, the modeled parental magma composition is that of an LREE-enriched high-MgO basalt, highly similar to the marginal series gabbronorite of the Näränkävaara layered 
Table 3 Representative results of EPMA chemical analyses and calculated cation fractions

\begin{tabular}{|c|c|c|c|c|c|c|c|}
\hline \multicolumn{8}{|l|}{ Chromites } \\
\hline Zone & Low-Fe & Low-Fe & Low-Fe & High-Fe & High-Fe & High-Fe & High-Fe \\
\hline Unit \# & 1 & 2 & 4 & 6 & 7 & 8 & 9 \\
\hline Rock type & Peridotite & Lherzolite & Dunite & Dunite & Dunite & Dunite & Dunite \\
\hline Cumulus* & oMCb? & $\mathrm{oOCb} * \mathrm{a} *(\mathrm{pf})$ & $\mathrm{oAC}$ & $\mathrm{oAC}$ & $\mathrm{oAC}$ & oCA & $\mathrm{oMC}(\mathrm{b} *)$ \\
\hline Sample $^{1}$ & 1 & 2 & 3 & 4 & 5 & 6 & 7 \\
\hline \multicolumn{8}{|c|}{ Major oxides (wt\%) } \\
\hline $\mathrm{SiO}_{2}$ & 0.06 & 0.34 & 0.06 & 0.00 & 0.05 & 0.10 & 0.10 \\
\hline $\mathrm{TiO}_{2}$ & 0.52 & 0.46 & 0.51 & 0.42 & 0.58 & 0.51 & 0.43 \\
\hline $\mathrm{V}_{2} \mathrm{O}_{5}$ & 0.15 & 0.50 & 0.13 & 0.19 & 0.18 & 0.20 & 0.26 \\
\hline $\mathrm{A}_{2} \mathrm{O}_{3}$ & 16.34 & 10.82 & 17.68 & 14.24 & 19.63 & 22.26 & 22.68 \\
\hline $\mathrm{Cr}_{2} \mathrm{O}_{3}$ & 45.01 & 38.84 & 46.82 & 50.09 & 44.49 & 41.55 & 42.99 \\
\hline $\mathrm{FeO}_{\mathrm{t}}$ & 30.76 & 42.48 & 26.34 & 28.36 & 27.49 & 26.57 & 23.80 \\
\hline $\mathrm{MnO}$ & 0.41 & 0.34 & 0.23 & 0.18 & 0.34 & 0.35 & 0.12 \\
\hline $\mathrm{MgO}$ & 5.26 & 4.04 & 7.50 & 5.36 & 6.53 & 7.51 & 9.23 \\
\hline $\mathrm{NiO}$ & 0.09 & 0.16 & 0.12 & 0.03 & 0.07 & 0.08 & 0.08 \\
\hline $\mathrm{ZnO}$ & 0.73 & 0.33 & 0.21 & 0.52 & 0.33 & 0.70 & 0.22 \\
\hline Total & 99.33 & 98.30 & 99.59 & 99.42 & 99.69 & 99.84 & 99.92 \\
\hline \multicolumn{8}{|c|}{ Calculated cation fractions (apfu) ${ }^{2}$} \\
\hline $\mathrm{Fe} 3+/ \sum$ trivalent & 010 & 031 & 010 & 005 & 005 & 006 & 004 \\
\hline $\mathrm{Cr} / \sum$ trivalent & 0.59 & 0.49 & 0.58 & 0.66 & 0.57 & 0.52 & 0.54 \\
\hline $\mathrm{Al} / \sum$ trivalent & 0.32 & 0.20 & 0.32 & 0.28 & 0.38 & 0.42 & 0.42 \\
\hline $\mathrm{Mg \#}$ & 0.26 & 0.19 & 0.34 & 0.27 & 0.32 & 0.36 & 0.43 \\
\hline $\mathrm{Cr} \#$ & 0.65 & 0.71 & 0.64 & 0.70 & 0.60 & 0.56 & 0.56 \\
\hline \multicolumn{8}{|l|}{ Olivines } \\
\hline Zone & Low-Fe & Low-Fe & High-Fe & High-Fe & & & \\
\hline Unit \# & 1 & 2 & 8 & 9 & & & \\
\hline Rockname & Peridotite & Peridotite & Serpentinite & Dunite & & & \\
\hline Cumulus* & oOCba? & $\mathrm{o}(\mathrm{c}) \mathrm{OCb} *\left(\mathrm{a}^{*}\right)$ & $\mathrm{oAC}$ & $\mathrm{oMC}(\mathrm{b} * \mathrm{c} *)$ & & & \\
\hline Sample $^{3}$ & 1 & 2 & 3 & 4 & & & \\
\hline \multicolumn{8}{|c|}{ Major oxides (wt\%) } \\
\hline $\mathrm{SiO}_{2}$ & 41.21 & 40.43 & 40.48 & 40.63 & & & \\
\hline $\mathrm{Al}_{2} \mathrm{O}_{3}$ & 0.009 & 0.013 & 0.022 & 0.007 & & & \\
\hline $\mathrm{Cr}_{2} \mathrm{O}_{3}$ & 0.015 & 0.019 & 0.025 & 0.021 & & & \\
\hline $\mathrm{FeO}_{\mathrm{t}}$ & 11.85 & 11.87 & 11.87 & 11.95 & & & \\
\hline $\mathrm{MnO}$ & 0.204 & 0.186 & 0.187 & 0.185 & & & \\
\hline $\mathrm{MgO}$ & 46.74 & 47.39 & 47.37 & 47.27 & & & \\
\hline $\mathrm{CaO}$ & 0.030 & 0.072 & 0.078 & 0.059 & & & \\
\hline $\mathrm{NiO}$ & 0.405 & 0.309 & 0.278 & 0.245 & & & \\
\hline $\mathrm{CoO}$ & 0.016 & 0.016 & 0.018 & 0.020 & & & \\
\hline Total & 100.48 & 100.31 & 100.32 & 100.39 & & & \\
\hline Mg\# & 87.55 & 87.68 & 87.68 & 87.58 & & & \\
\hline \multicolumn{8}{|l|}{ Pyroxenes } \\
\hline Zone & Low-Fe & Low-Fe & High-Fe & High-Fe & & & \\
\hline Unit \# & 2 & 2 & 5 & 8 & & & \\
\hline Rockname & Peridotite & Peridotite & Bronzitite & Dunite & & & \\
\hline Cumulus* & $\mathrm{o}(\mathrm{c}) \mathrm{OCb}^{*}\left(\mathrm{a}^{*}\right)$ & $\mathrm{o}(\mathrm{c}) \mathrm{OCb}^{*}\left(\mathrm{a}^{*}\right)$ & $\mathrm{bAC}$ & $\mathrm{oAC}$ & & & \\
\hline Sample $^{4}$ & 1 & 1 & 2 & 3 & & & \\
\hline Mineral $^{5}$ & Opx & $\mathrm{Cpx}$ & Opx & $\mathrm{Cpx}$ & & & \\
\hline
\end{tabular}


Table 3 (continued)

\begin{tabular}{lllll}
\hline Major oxides (wt $)$ & & & & \\
$\mathrm{SiO}_{2}$ & 55.97 & 51.59 & 55.80 & 52.53 \\
$\mathrm{TiO}_{2}$ & 0.08 & 0.71 & 0.07 & 0.37 \\
$\mathrm{Al}_{2} \mathrm{O}_{3}$ & 1.52 & 3.03 & 1.08 & 3.91 \\
$\mathrm{FeO}_{\mathrm{t}}$ & 7.59 & 4.27 & 7.29 & 3.51 \\
$\mathrm{MnO}$ & 0.18 & 0.15 & 0.20 & 0.11 \\
$\mathrm{MgO}$ & 33.05 & 18.30 & 33.74 & 16.85 \\
$\mathrm{CaO}$ & 1.88 & 20.17 & 1.41 & 20.84 \\
$\mathrm{Na}$ & 0.00 & 0.44 & 0.00 & 0.72 \\
$\mathrm{Cr}$ & 0.69 & 1.05 & 0.60 & 1.03 \\
$\mathrm{NiO}$ & 0.09 & 0.04 & 0.07 & 0.03 \\
$\mathrm{Total}$ & 101.15 & 100.00 & 100.36 & 100.00 \\
$\mathrm{Calculated}$ cation fractions $($ apfu & 6 & & & \\
$\mathrm{Mg \#}$ & 0.89 & 0.88 & 0.89 & 0.90 \\
$\mathrm{En}$ & 85.31 & 51.07 & 86.67 & 48.43 \\
$\mathrm{Fs}$ & 11.20 & 6.87 & 10.72 & 5.83 \\
Wo & 3.50 & 40.46 & 2.60 & 43.05 \\
\hline
\end{tabular}

$\mathrm{FeO}_{\mathrm{t}}=$ total $\mathrm{FeO}$

* Cumulus nomenclature after Irvine (1982), with exceptions that intercumulus phases marked as suffix, minerals $<5$ vol\% mode marked with parentheses, and poikilitic phases marked with asterisk

${ }^{1}$ Samples (drill hole \& depth): 1) R9 219.3 m; 2) R8 141.0 m; 3) R4 170.7 m; 4) VJJA-2017-57.1 (surface); 5) JSN-89 (surface); 6) VJJA-2018-81.1 (surface); 7) R2 $237.9 \mathrm{~m}$

${ }^{2}$ Chromite analyses calculated to an ideal ülvospinel formula (4 oxygens) according to Barnes (1998); sum of trivalent cations $=\left(\mathrm{Cr}+\mathrm{Ti}+\mathrm{V}+\mathrm{Al}+\mathrm{Fe}{ }^{3+}\right)$; $\mathrm{Mg} \#=\mathrm{Mg} /\left(\mathrm{Mg}+\mathrm{Fe}^{2+}\right) ; \mathrm{Cr} \#=\mathrm{Cr} /(\mathrm{Cr}+\mathrm{Mg})$

${ }^{3}$ Samples (drill hole \& depth): 1) R6 89.8 m; 2) TTK-4.1 m; 3) VJJA-2017-81.1 m; 4) R2 237.9 m

4 Samples: 1) TTK-4.1 (surface); 2) VJJA-2017-55.2 (surface); 3) VJJA-2017-81.1 (surface)

${ }^{5}$ Orthopyroxene $=\underline{O p x}$; Clinopyroxene $=C p x$

${ }^{6} 6$ oxygens per formula unit, $\mathrm{En}=\mathrm{Mg} /\left(\mathrm{Mg}+\mathrm{Fe}^{2+}+\mathrm{Fe}^{3+}+\mathrm{Ca}+\mathrm{Mn}\right), \mathrm{Fs}=\left(\mathrm{Fe}^{2+}+\mathrm{Fe}^{3+}+\mathrm{Mn}\right) /\left(\mathrm{Mg}+\mathrm{Fe}^{2+}+\mathrm{Fe}^{3+}+\mathrm{Ca}+\mathrm{Mn}\right), \mathrm{Wo}=\mathrm{Ca} /\left(\mathrm{Mg}+\mathrm{Fe}^{2+}+\mathrm{Fe}^{3+}+\mathrm{Ca}+\mathrm{Mn}\right)$
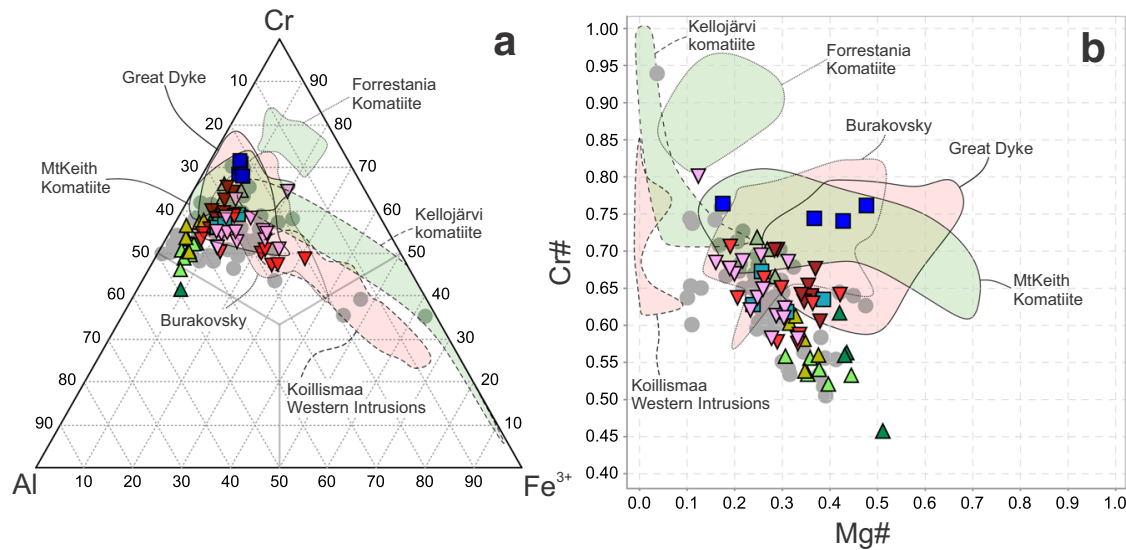

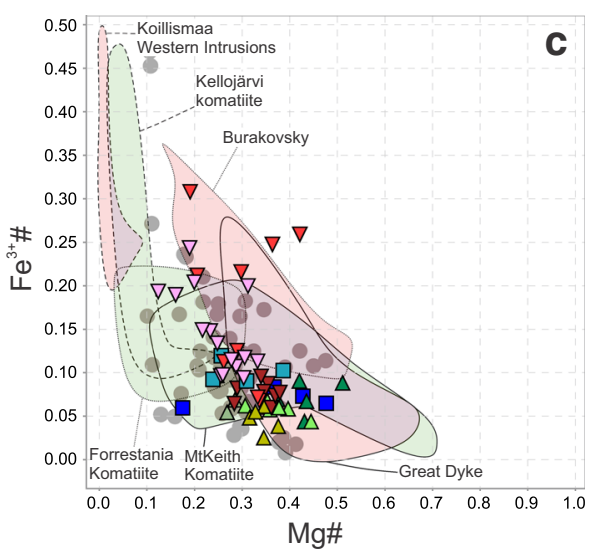

Basal dunite - High-Fe zone

$\square$ Unit 10 - Harburgite and bronzitite

$\triangle$ Unit 9 - Olivine-orthopyroxene heteradcumulate

$\triangle$ Unit 8 - Olivine adcumulate

$\triangle$ Unit 7 - Olivine adcumulate (low-Mg\#)

$\triangle$ Unit 6 - Olivine adcumulate

Unit 5 - Orthopyroxenite

(Wilson 1982; Chistyakov and Sharkov 2008; Karinen 2010; Bailly et al. 2011). Results of chromite analyses have been recalculated assuming stoichiometry to an ideal $\mathrm{XY}_{2} \mathrm{O}_{4}$ formula according to Barnes (1998); $\mathrm{Mg \#}=$ $\mathrm{Mg} /\left(\mathrm{Mg}+\mathrm{Fe}^{2+}\right) ; \mathrm{Cr} \#=\mathrm{Cr} /(\mathrm{Cr}+\mathrm{Mg}) ; \mathrm{Fe}^{3+} \#=\mathrm{Fe}^{3+} /\left(\mathrm{Fe}^{3+}+\mathrm{Mg}+\mathrm{Cr}\right)$ 


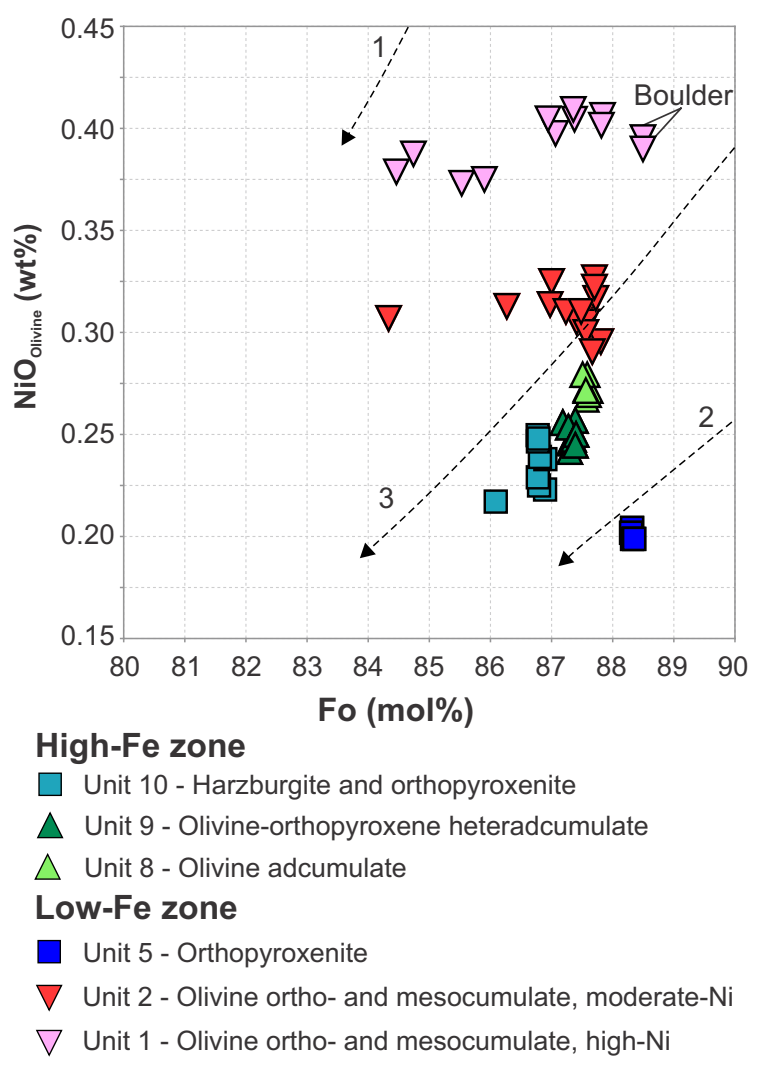

Fig. 11 Olivine Fo versus $\mathrm{NiO}$ compositions in the Näränkävaara basal dunite. The three compositional groups in olivines (high-, moderate-, and low-Ni) reflect whole-rock $\mathrm{MgO}$ versus $\mathrm{Ni}$ compositions (see Fig. 6e), with Ni-richest olivines found in the border zone ortho- and mesocumulates (units \#1-2). Post-cumulus re-equilibration of olivine with trapped liquid typically results in trends of decreasing Fo as shown by unit \#2 (Barnes 1986). Olivine fractional crystallization models shown in dashed black lines (modeled with COMAGMAT 5.5.2; $\mathrm{Fe}_{2} \mathrm{O}_{3}$ of $0.1 \times$ $\mathrm{FeO}$; oxygen fugacity buffered at quartz-magnetite-fayalite; Ariskin and Barmina 2004) for average modeled parental magma compositions of (1) unit \#1 of the basal dunite, (2) unit \#2 of the basal dunite; and for the (3) marginal series gabbronorite of the Näränkävaara layered series (Järvinen et al. 2020)

series (Figs. 8 and 9, and Table 2; marginal series plotted as a star in all variation diagrams) (Järvinen et al. 2020). The marginal series gabbronorite has a Mg\# of 74 and thus is in equilibrium with $\mathrm{F}_{90-90.6}$ olivine $\left(\mathrm{K}_{\mathrm{D}} 0.30-0.33\right)$, similar to the most primitive olivine inferred from the basal dunite (Fig. 5). These results suggest a comagmatic origin for the basal dunite and the Näränkävaara layered series.

Large uncertainty to the model results presented here is caused by scatter in whole-rock $\mathrm{MgO}$ and $\mathrm{FeO}$ contents (Fig. 5). Some of this may be related to iron mobility during serpentinization, as secondary magnetite veinlets are relatively common in drill core. Several other significant sources of error are also related to the methods used here, discussed in more detail in e.g. Arndt et al. (2008).
Inner structure and differentiation of the basal dunite

\section{Layered structure}

The same succession of cumulates and geochemical variations are found in both the SE and NW blocks of the basal dunite, in two separate cross-sections $25 \mathrm{~km}$ apart (Fig. 2a) (this study and Järvinen et al. 2020). In cross-section in both blocks, from SW to NE, ortho- and mesocumulates are followed by adcumulates and finally olivine orthopyroxene heteradcumulates before the layered series contact. Geochemically, both begin with a low-Fe zone followed by a high-Fe zone, with whole-rock and olivine compositions showing decrease in $\mathrm{Mg \#}$ and $\mathrm{Ni}$ contents towards the layered series (Figs. 7a and c; see also Fig. S1). The sequence of highand low-Cr cumulates (Fig. 7d), reflecting the amount of euhedral (cumulus) chromite, is also the same on both blocks. These observations indicate that the structure of the basal dunite is at least somewhat layered and remains similar over the $30 \mathrm{~km}$ strike length of the intrusion.

\section{Ortho- and mesocumulates of the border zone}

Olivine orthocumulates are found in both komatiite flows and mafic-ultramafic layered intrusions (Campbell 1987; Hill et al. 1995). Orthocumulate units of similar thickness as in the basal dunite (Fig. 2c) are common along the margins of komatiite flows, with modal olivine increasing inwards with distance from the wall-rock contact (Gole and Barnes 2020). In comparison, the Aganozero-block of the 2.44 Ga Burakovsky layered intrusion in Russian Karelia (Fig. 1; Amelin et al. 1995) contains a 100 $200 \mathrm{~m}$ thick olivine orthocumulatic marginal sequence interpreted as a marginal series for the intrusion (Nikolaev and Ariskin 2005), with similar modal and geochemical variation as found in the Näränkävaara ortho- and mesocumulates. As the low-Fe zone represents the most primitive part of the Näränkävaara basal dunite - and as the orthocumulates of the low-Fe zone can be modeled as mixtures between the most primitive olivine found and a trapped melt in equilibrium with this olivine - we suggest that the ortho- and mesocumulate border zone (units\# 1-2) represents a marginal series of sorts similar to the referred examples. Orthocumulate textures have likely developed by relatively rapid cooling of olivine-bearing magma against a cool wall-rock leading to early crystallization of intercumulus minerals (Campbell 1987).

\section{Adcumulates and heteradcumulates}

Over $90 \%$ of the $\sim 1.5-2.5 \mathrm{~km}$ thick Näränkävaara basal dunite consists of olivine adcumulates (Fig. 2c). Olivine adcumulates are thought to be formed by in-situ crystallization on the crystal-liquid interface, with continuous low-porosity crystal growth facilitated either by diffusion combined with 
convective extraction of solute in near-equilibrium low-heat flux conditions (e.g., slow-cooling magma chamber) (Campbell 1987; Walker et al. 1988) or by turbulent flow of low-viscosity magma flushing away the depleted solute from the crystal-melt interface (e.g., komatiite flow) (Hill et al. 1995).

The adcumulate units of the Näränkävaara basal dunite exhibit some features typically described from high-volume turbulent komatiite flows. In the low-Fe zone, adcumulates contain smooth sinusoidal fluctuations in Mg\# with height (Fig. 7a, see unit \#4 at 350-550 m). Similar fluctuations in komatiitic cumulates have been interpreted as evidence of crystallization in an open system with continuous influx of magmas with variable $\mathrm{MgO}$ content (Arndt et al. 2008). In addition, the high-Fe zone adcumulates commonly contain poikilitic chromite (Fig. 4c-d), and rarely also bimodal olivine (Fig. 3f). Both are thought to form in open system turbulent flows in komatiite settings (Barnes 1998; Gole and Barnes 2020). Poikilitic chromite in adcumulates cannot form from trapped intercumulus liquid alone, as the solubility of $\mathrm{Cr}$ in basaltic and komatiitic magmas is low ( 3000 ppm). Rather, poikilitic chromite is thought to crystallize competitively with olivine in conditions of chromite supersaturation but inhibited nucleation (Godel et al. 2013). Such conditions may exist in freely convecting magma chambers or channels under conditions of low supercooling, where chromite supersaturation is reached only locally and transiently; e.g. in hot turbulent komatiite flows (Barnes 1998). In contrast, euhedral chromite is typically found in more static settings with low cooling rates, e.g. in differentiated flows (Barnes 1998) and in layered intrusions. In Archean komatiites, poikilitic chromite is typically found in adcumulates with $\mathrm{Fo}_{92-93}$ and euhedral chromite below $\mathrm{Fo}_{91}$, with the high Fo contents associated with poikilitic chromite indicating high crystallization temperatures close to chromite liquidus (Barnes 1998). Here, those Fo limits seem to have been shifted down about 3 mol\% (Table 1). As far as we know, these are the lowest Fo rocks where poikilitic chromite has been reported. An additional complication is that, unlike in komatiites, poikilitic chromite in Näränkävaara appears to be associated with the lowest Fo olivine adcumulates rather than the highest (Table 1), implying that some other factor than temperature has inhibited chromite nucleation. Also, although modeling indicates a relatively high liquidus temperature between 1300 and $1415^{\circ} \mathrm{C}$ for the basal dunite parental magma (COMAGMAT 5.5.2 with oxygen fugacity buffered at quartz-fayalite-magnetite; Ariskin and Barmina 2004), that is close to or above chromite liquidus ( $\sim 1350{ }^{\circ} \mathrm{C}$; Murck and Campbell 1986), it is not clear whether such a dynamic turbulently flowing magma system as prescribed by Barnes (1998) could exist in an intrusive environment. In an intrusive setting, poikilitic chromite has only been described from the Dumont sill in Canada (Duke 1986). Resolving how the poikilitic chromite in Näränkävaara formed is outside the scope of this paper, but its ubiquitous presence in the high-Fe zone adcumulates in association with bimodal olivine suggests the possibility that these adcumulates were at least partly formed in a high flow-through environment.

Whether the adcumulates of the basal dunite were formed in a high-volume system or not, the composition of the in-situ formed olivine should reflect the composition and differentiation of the melt from which it formed. Generally, whole-rock Mg\# and Ni (as well as olivine and chromite Ni) decrease from SW to NE towards the layered series contact (Fig. 7), suggesting differentiation by olivine fractionation from $\mathrm{Fo}_{90-91}$ down to $\mathrm{Fo}_{87-86}$. There are, however, at least two distinct breaks or reversals indicated by Mg\#. The first break is marked by the lowermost orthopyroxenite unit that separates the low-Fe and high-Fe zones (unit \#5 in Fig. 7a), and the second by a relatively low-Mg\# adcumulate in the high-Fe zone (unit \#7 in Fig. 7a). At least the latter is likely related to an influx of more primitive magma.

Difference in average compositions between the low-Fe and high-Fe zones is quite large in regard to $\mathrm{MgO}, \mathrm{FeO}_{\mathrm{t}}$, and $\mathrm{Ni}$ (Fig. $6 \mathrm{a}$ and e). The olivine Fo-content at the beginning of orthopyroxene crystallization also differs between the two zones. Orthopyroxene first appears on the liquidus in the low-Fe zone at $\mathrm{Fo}_{89}$ (orthopyroxenite unit \#5 in Fig. 7a), and a second time in the high-Fe zone at $\mathrm{Fo}_{87.5}$ (heteradcumulate unit \#9). This indicates slightly different liquid lines of descent, and suggests a more significant change in parental magma composition between the low-Fe and high-Fe zones (fractionation in staging chamber?). The low-Fe zone may represent a single magmatic system, beginning with formation of the border zone orthocumulates (units \#1-2), followed by possible open system flow and formation of adcumulates (units \#3-4), and ending in closed system pooling, fractionation, and formation of the lowermost orthopyroxenite (unit \#5).

Similar olivine orthopyroxene heteradcumulates as in unit \#9 (Fig. 2c) are found in a similar position (preceding the layered series contact) in the NW block of the intrusion, $25 \mathrm{~km}$ to the NW (Järvinen et al. 2020). In the NW block, the heteradcumulates are in contact with, or grade into, the basal harzburgite of the Näränkävaara layered series. These NW contact zone heteradcumulates and layered series basal harzburgite compositions are plotted as grey crosses in variation diagrams in Figs. 4, 5 and 6. These compositions closely match those of units \#9 and \#10 in the SE block. At least for the high-Fe zone, this suggests the basal dunite and layered series magmas were following identical liquid lines of descent, having been locked-in to the same olivine-orthopyroxene-(chromite?) peritectic at an olivine composition of approximately $\mathrm{Fo}_{87.5}$.

\section{Archean or Proterozoic origin?}

The parental magma composition and liquid line of descent of the Näränkävaara basal dunite seem to be strikingly similar to that of the neighboring 2.44 Ga mafic-ultramafic layered series. However, the basal dunite exhibits many features typical of Archean komatiitic cumulates, except with distinctly lower- 
Fo olivine as noted above. As the Näränkävaara intrusion is located between the Takanen and Suomussalmi greenstone belts (Fig. 2a), both containing Archean komatiites (Iljina 2003; Lehtonen et al. 2017), the hypothesis that the dunite body could represent an older komatiitic wall-rock for the layered series must also be considered.

The nearby Suomussalmi and Takanen komatiites are relatively thin olivine \pm clinopyroxene cumulates and flows with average $\mathrm{Al}_{2} \mathrm{O}_{3} / \mathrm{TiO}_{2}$ ratios of 17-19. Chondrite-normalized REEpatters are flat or LREE-depleted (Papunen et al. 2009; V. Järvinen unpublished data), except for the Vaara locality which shows roughly similar LREE-enriched patterns as the Näränkävaara basal dunite (Konnunaho et al. 2013). Vaara is the only nearby komatiite body with similar high-Mg and lowCr olivine adcumulates as found in Näränkävaara (see Fig. 4), but it is significantly smaller in volume. The uniformity of the inner structure of the Näränäkävaara basal dunite along a strike length of $30 \mathrm{~km}$ would only be expected in proximal conduit or large scale channel facies komatiite flows (Gole and Barnes 2020). The 2.79 Ga Kellojärvi ultramafic cumulate complex, located about $100 \mathrm{~km}$ south of Näränkävaara in the Kuhmo greenstone belt of the Suomussalmi-Kuhmo-Tipasjärvi greenstone complex, is the closest comparison of komatiitic origin to the basal dunite (Papunen et al. 2009; Lehtonen et al. 2016). The Kellojärvi complex is $3-5 \mathrm{~km}$ thick and primarily composed of metamorphosed olivine ortho-, meso-, and adcumulates with similar petrography as in Näränkävaara, with the exception of clinopyroxene being the primary pyroxene instead of orthopyroxene. The general lithology of the Kellojärvi complex is also similar, with $\mathrm{a}<50 \mathrm{~m}$ thick border zone composed of olivine orthocumulate and minor pyroxenites (with basement xenoliths), grading into dunite towards the center of the body (Tulenheimo 1999; Papunen et al. 2009). Highest measured igneous olivine Fo contents $\left(\mathrm{Fo}_{82-89}\right)$ (Tulenheimo 1999) and whole-rock geochemistry are quite similar to Näränkävaara (Fig. 6). Kellojärvi parental magma composition has been inferred from whole-rock compositions to have $23 \mathrm{wt} \% \mathrm{MgO}$ (Makkonen et al. 2017), and the highest Fo content inferred from whole-rock Mg\#‘s is about $\mathrm{Fo}_{92}$, which are both somewhat higher compared to the estimates from Näränkävaara presented here. These differences, as well as the differences in trace element ratios (Figs. 8 and 9), could be explained by Näränkävaara having formed from a more strongly differentiated and crustally contaminated komatiitic magma.

One observation against a komatiitic origin is that compared to typical komatiitic olivine (Arndt et al. 2008) the olivines from the Näränkävaara basal dunite have distinctly lower $\mathrm{Cr}_{2} \mathrm{O}_{3}(<0.05$ wt $\%$ versus $0.15-0.5 \mathrm{wt} \%)$ and $\mathrm{CaO}$ $(<0.15 \mathrm{wt} \%$ versus $0.2-0.35 \mathrm{wt} \%)$. The low $\mathrm{CaO}$ content of olivines in Näränkävaara suggests a high-pressure intrusive environment (Simkin and Smith 1970). The higher degree of serpentinization in the basal dunite compared to the layered series is not thought to be significant evidence for either hypothesis because peridotitic rocks in the layered series are typically strongly serpentinized and fresh orthopyroxenites are in turn found in the basal dunite (unit \#5).

Overall, the highly similar parental magma compositions, liquid lines of descent, and roughly congruent layered structures between the Näränkävaara basal dunite and layered series argue for a common intrusive origin. There are no other 2.44 Ga layered intrusions in northern Finland with such an extensive basal dunite as the Näränkävaara intrusion, however. Closest correlatives are the $\sim 2.44 \mathrm{Ga}$ Burakovsky layered intrusion (Chistyakov and Sharkov 2008) and the komatiitic basalts of the Vetreny belt (Puchtel et al. 1997), both found in Russian Karelia (Fig. 1). The two are considered comagmatic, with parental magmas between 13 and $18 \mathrm{wt} \% \mathrm{MgO}$, and similar trace and isotopic compositions (Puchtel et al. 1997; Nikolaev and Ariskin 2005; Kulikov et al. 2010). As shown in Figs. 4, 6, 8, and 9, geochemistry of the Näränkävaara basal dunite is extremely similar to the Vetreny belt extrusives. The Aganozero-block of the Burakovsky intrusion also hosts an up to $6 \mathrm{~km}$ thick basal dunite composed of homogeneous olivine adcumulate, with olivine compositions $\mathrm{Fo}_{82-90}$ (Nikolaev and Khorov 2003), interpreted to have formed by repeated recharge of high-MgO magma (Chistyakov and Sharkov 2008). In addition, the marginal series orthocumulate in the Aganozero-block is similar to the Näränkävaara border zone, as discussed previously.

Kulikov et al. (2010) proposed that the igneous formations of the Vetreny belt, together with similar formations in Kola and northern Finland, are parts of at least two intermixed large igneous provinces (LIP) spanning 2.5-2.4 Ga, with related intrusive, hypabyssal, and extrusive rocks. The rocks share similar characteristics of a crustally contaminated komatiitic (plume-related) magma, with 9-18 wt $\% \mathrm{MgO}, 0.5-1 \mathrm{wt} \% \mathrm{TiO}_{2}$, LREE-enrichment, and an average initial $\varepsilon_{\mathrm{Nd}}$ of -2 (intrusions) to -0.4 (extrusives). Isotope data are not available from Näränkävaara, but otherwise the inferred parental magmas for the Näränkävaara layered series (Järvinen et al. 2020), and for the basal dunite presented here, are in line with the results presented for the Vetreny belt (Puchtel 1997; Kulikov et al. 2010).

An open question is whether the komatiitic features indicating low-viscosity turbulent flow can form in an intrusive setting from a high-Mg basaltic magma in equilibrium with $\sim \mathrm{Fo}_{90}$ olivine? We suggest that the Näränkävaara basal dunite represents a (subvolcanic?) sill or chamber with intermittent high volume flow-through of high-MgO basaltic magma possibly evolving towards lower $\mathrm{MgO}$ content with time. Formation of a marginal series between the basal dunite and layered series indicates a longer hiatus in magmatism, with again at least three (relatively much smaller) magma pulses forming the Näränkävaara layered series (Järvinen et al. 2020).

Overall, available evidence suggest that the Näränkävaara intrusion formed in an open system dynamic magmatic environment (sill-dyke network?) with several discrete pulses of different magmas with different $\mathrm{MgO}$ and Ni contents, but 
with a uniform origin. Näränkävaara may have acted as a magmatic feeder channel related to the Koillismaa layered intrusion complex and the "Hidden dyke" (Fig. 1) as suggested by Alapieti (1982), and more generally as a magmatic center related to the Fennoscandian LIPs as suggested by Kulikov et al. (2010). In terms of their composition, volcanic rocks found in the Saari-Kiekki greenstone belt in eastern Finland (Luukkonen 1989) could be viewed as differentiates of the Näränkävaara basal dunite and layered series parental magmas (Järvinen et al. 2020; this study). Although these volcanic rocks have not been precisely dated, they may represent extrusive equivalents of the Finnish 2.44 Ga layered intrusions. Nevertheless, extrusive rocks of this age group have not been definitively identified from Finland, so it is possible that either (1) the magmatic systems never vented, (2) they have been eroded away, or (3) the lavas all flowed into the Karelia-Kola rift now located in Russian Karelia.

Although we prefer the origin of the Näränkävaara basal dunite in relation to the layered series in the light of the presented evidence and discussion, we emphasize that its petrogenesis is not settled in the absence of absolute age or other isotopic data, which have proven difficult to acquire from the serpentinized ultramafic rocks.

\section{Mineral potential for orthomagmatic Ni-(Cu-Co-PGE) deposits}

The Näränkävaara basal dunite represents a large volume of ultramafic cumulates derived from a mantle plume source in an area with large trans-crustal structures, and its mineral potential for Ni-(Cu-Co-PGE) is of great interest (Barnes et al. 2016a). Similar Cr-poor olivine cumulates as found in Näränkävaara (Fig. 4) have been found prospective for komatiite-hosted NiCu-PGE deposits in Finland (Konnunaho 2016).

There is a distinct difference in average whole-rock $\mathrm{Ni}$ contents between the low-Fe zone (2200 ppm Ni) and the high-Fe zone (1780 ppm Ni) (Fig. 6e). This Ni-depletion is reflected in olivine compositions (Fig. 11; 3200 ppm versus 2150 ppm Ni), chromite (1500 ppm versus 390 ppm Ni), and to a lesser extent also in pyroxenes. Because the Ni-depletion appears in samples with the same $\mathrm{Mg \#}$ and forsterite contents, it cannot be related to simple fractionation of olivine, even if the trapped liquid shift to lower Fo contents is taken into account (Fig. 10) (Barnes 1986). Rather, this suggests either a more Ni-rich parental magma for the low-Fe zone compared to the high-Fe zone, or that the Ni-depletion is caused by sulfide saturation and segregation at some stratigraphic level.

No significant amounts of magmatic sulfides have been found in the Näränkävaara area. Trace sulfides are commonly found in the NW border zone olivine ortho- and mesocumulates. A basaltic magma becomes sulfur-saturated at approximately $1000 \mathrm{ppm} \mathrm{S}$ (Li and Ripley 2005). Assuming total incompatibility of sulfur in olivine, an olivine cumulate with 10 vol\% trapped intercumulus melt (and 90 vol\% olivine) would, at sulfur saturation, contain approximately $0.10 \times 1000=100 \mathrm{ppm} \mathrm{S}$. Of the border zone samples (units \#1-2), 62 out of 69 are above the detection limit of 100 ppm S, containing between 100 and 1200 ppm S (average of $480 \mathrm{ppm}$ ). These samples contain about 75-95 vol\% cumulus olivine, suggesting that the trapped intercumulus melt contained in the samples may have been sulfur saturated at the time of emplacement. However, $\mathrm{Cu}, \mathrm{Pd}$, and $\mathrm{Pt}$ do not correlate with increasing $\mathrm{S}$ contents, suggesting that these sulfides equilibrated with a small volume of magma and possibly formed after emplacement.

$\mathrm{Pt}$, and to a lesser extent Pd, behave similarly to other incompatible elements with their concentrations increasing with decreasing cumulus olivine (Fig. 12). Only 8 samples, all from the moderate-Ni orthocumulate (unit \#2), are above detection limit for $\mathrm{Cu}$ and $\mathrm{Pd}$, with $\mathrm{Cu} / \mathrm{Pd}$ ratios between 8000 and 40,000 (Fig. 12d). These are above primitive mantle ratio or about 8000 (McDonough and Sun 1995) which suggests sulfur saturation before emplacement. Ratios of $\mathrm{Pd} / \mathrm{TiO}_{2}$ and $\mathrm{Pt} / \mathrm{TiO}_{2}$ in the basal dunite are generally below primitive mantle ratio (Fig. 12c), also suggesting either previous sufide saturation or sulfide retention in the source. Few samples from the high-Ni border zone orthocumulates (unit \#1) show ratios above primitive mantle, which together with the generally more primitive nature of this unit suggests that it may have formed from a less PGE-depleted magma compared to unit \#2. However, as most assays are below or close to detection limits with high relative errors, more precise analyses are required to assess the sulfide saturation history of the basal dunite in more detail.

\section{Conclusions}

The Näränkävaara basal dunite is a $1.5-2 \mathrm{~km}$ thick series of ultramafic cumulates stratigraphically below the $2.44 \mathrm{Ga}$ Näränkävaara layered series. It contains a 200-300 m thick border zone along the southern basement contact composed of olivine meso- and orthocumulates, but is otherwise composed of olivine adcumulates with lesser poikilitic olivine-orthopyroxene heteradcumulates and minor orthopyroxenites. Textural and geochemical layering in the basal dunite remains similar for the $30 \mathrm{~km}$ strike length of the body. Geochemically, the dunite is composed of a more primitive low-Fe zone along the basement contact (average $\mathrm{FeO}_{\mathrm{t}}$ of $10.2 \mathrm{wt} \%$ and $\mathrm{Ni}$ of $2250 \mathrm{ppm}$ with Mg\# 85.3-90.4), and a more evolved high-Fe zone in contact with the layered series (average $\mathrm{FeO}_{\mathrm{t}}$ of $12.5 \mathrm{wt} \%$ and $\mathrm{Ni}$ of 1700 ppm with Mg\# 85.2-87.7). A distinct Ni-depletion in olivine is found in the low-Fe zone to the high-Fe zone (3200 versus 2200 ppm Ni). This depletion does not correlate with olivine Fo contents, suggesting it is not related to olivine fractionation. 
Hence the basal dunite may have potential for $\mathrm{Ni}-(\mathrm{Cu}-\mathrm{Co}-\mathrm{PGE})$ sulfide mineralization.

The basal dunite parental magma composition has been modeled based on olivine-melt mixing lines inferred from the border zone ortho- and mesocumulates. It is an LREEenriched high-MgO (13-18 wt.\%) basalt that exhibits highly similar major and trace element composition with the parental magma of the neighboring layered series.

The presence of abundant low-porosity adcumulates, sometimes with poikilitic chromite and bimodal olivine, together with pyroxenitic interlayers and at least two compositional reversals, suggests formation in a dynamic magmatic setting with high flow-through of picritic magma, interrupted by periods of pooling and differentiation. Differences in compositions of the low-Fe and high-Fe zones imply a change in parental magma composition with time.

The presence of a marginal series between the basal dunite and the layered series indicates that the basal dunite is older
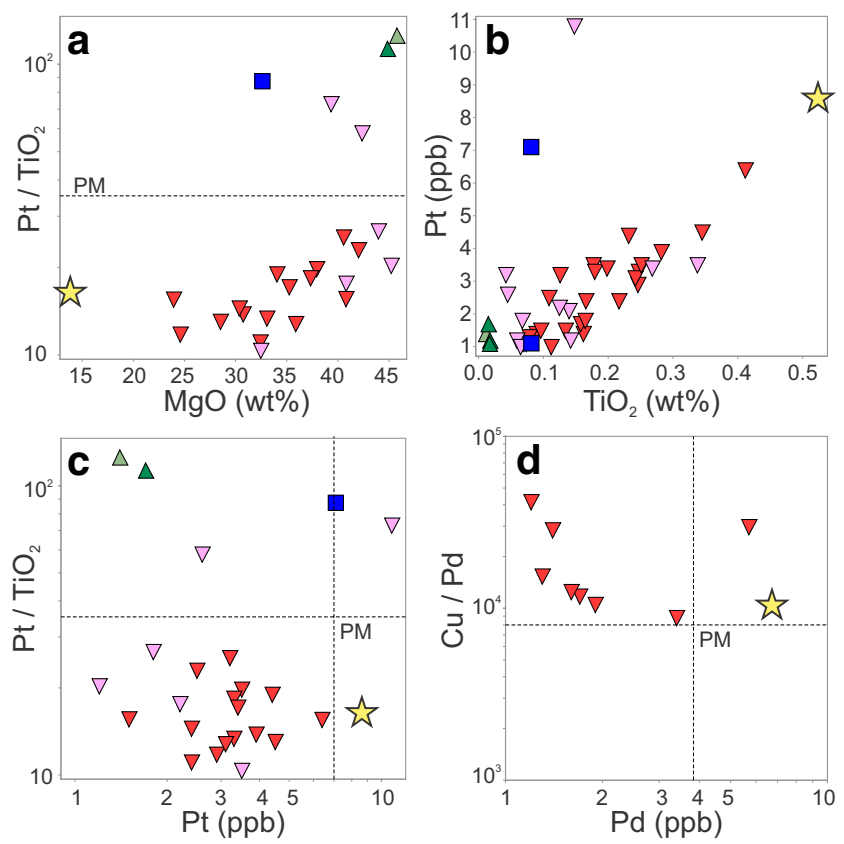

\section{Layered series \\ Tे Marginal series (R1 $173 \mathrm{~m}$ ) \\ Basal dunite - High-Fe zone \\ $\triangle$ Unit 9 - Olivine-orthopyroxene heteradcumulate \\ $\triangle$ Unit 6 - Olivine adcumulate \\ Basal dunite - Low-Fe Zone \\ Unit 5 - Orthopyroxenite \\ $\nabla$ Unit 2 - Olivine ortho- and mesocumulate, moderate-Ni \\ $\nabla$ Unit 1 - Olivine ortho- and mesocumulate, high-Ni}

Fig. 12 a-d Whole-rock chalcophile element diagrams of Näränkävaara basal dunite whole-rock samples. Primitive mantle values shown in dashed lines labeled "PM" (McDonough and Sun 1995). $\mathrm{Pt} / \mathrm{TiO}_{2}$ ratios below primitive mantle, and $\mathrm{Cu} / \mathrm{Pd}$ ratios above primitive mantle suggest sulfur saturation before emplacement. Detection limit for Pt and Pd is $1 \mathrm{ppb}$ than the layered series. The basal dunite is suggested to have formed in an early magmatic feeder channel related to the same Fennoscandian plume-related magmatism that produced the 2436 Ma Näränkävaara layered series and the other layered intrusions of the terrane. However, an alternative origin as an Archean komatiitic wall-rock cannot be ruled out.

Acknowledgements The Ni-Cu-Co-PGE projects of the Geological Survey of Finland are thanked for providing the materials and analyses required for this study. All new whole-rock analyses have been made at Eurofins Labtium Oy laboratories, Kuopio, Finland, and EPMA measurements were made at the Finnish Geosciences Research Laboratory, Espoo, Finland. Lassi Pakkanen is thanked for his diligent work on the mineral analyses used in this study. Three anonymous reviewers and editor Lutz Nasdala are thanked for their very helpful comments that greatly improved the manuscript. V.J. is indebted to the K.H. Renlund foundation for providing a $\mathrm{PhD}$ grant. J.S.H. was supported by Academy of Finland Grant 295129.

Funding Open access funding provided by University of Helsinki including Helsinki University Central Hospital.

Open Access This article is licensed under a Creative Commons Attribution 4.0 International License, which permits use, sharing, adaptation, distribution and reproduction in any medium or format, as long as you give appropriate credit to the original author(s) and the source, provide a link to the Creative Commons licence, and indicate if changes were made. The images or other third party material in this article are included in the article's Creative Commons licence, unless indicated otherwise in a credit line to the material. If material is not included in the article's Creative Commons licence and your intended use is not permitted by statutory regulation or exceeds the permitted use, you will need to obtain permission directly from the copyright holder. To view a copy of this licence, visit http://creativecommons.org/licenses/by/4.0/.

\section{References}

Akkerman JH (2008) Koillismaa-Naranka project (2005-2007). Geol Surv Finl, Hakku-database, Exploration report, 42 pp

Alapieti T (1982) The Koillismaa layered igneous complex, Finland - its structure, mineralogy and geochemistry, with emphasis on the distribution of chromium. Geol Surv Finl Bull 319:116

Alapieti T, Filén BA, Lahtinen J, Lavrov MM, Smolkin VF, Voitsekhovsky SN (1990) Early Proterozoic layered intrusions in the northeastern part of the Fennoscandian shield. Mineral Petrol 42(1-4): 1-22

Alapieti T, Hugg R, Piirainen T, Ruotsalainen A (1979) The ultramafic and mafic intrusion at Näränkävaara, northeastern Finland. Geol Surv Finl, Report of Investigation 35:31

Alapieti T, Lahtinen J (2002) Platinum-group element mineralization in layered intrusions of northern Finland and the Kola peninsula, Russia. In: Cabri LJ (ed) The geology, geochemistry, mineralogy and mineral beneficiation of platinum-group elements, CIM Spec vol 54, 507-546

Amelin YV, Heaman LM, Semenov VS (1995) U-Pb geochronology of layered mafic intrusions in the eastern Baltic shield: implications for the timing and duration of Paleoproterozoic continental rifting. Precambrian Res 75(1-2):31-46

Ariskin AA, Barmina GS (2004) COMAGMAT: development of a magma crystallization model and its petrologic applications. Geochem Int 42(Suppl 1):157 
Arndt N, Lesher CM, Barnes SJ (2008) Komatiite. Cambridge University Press, Cambridge, $\mathrm{p} 467$

Auranen O (1969) Näränkävaaran ultraemäksinen massiivi. MSc thesis, University of Oulu, pp 55

Bailly L, Augé T, Trofimov N, Golubev A, Tkachev A, Cherkasov S, Cassard D (2011) The mineralization potential of the Burakovsky layered intrusion, Karelia, Russia. Can Min 49:1455-1478

Barnes SJ (1986) The effect of trapped liquid crystallization on cumulus mineral compositions in layered intrusions. Contrib Mineral Petrol 93(4):524-531

Barnes SJ (1998) Chromite in komatiites, 1. Magmatic controls on crystallization and composition. J Petrol 39(10):1689-1720

Barnes SJ, Cruden AR, Arndt N, Saumur BM (2016a) The mineral system approach applied to magmatic $\mathrm{Ni}-\mathrm{Cu}-\mathrm{PGE}$ sulphide deposits. Ore Geol Rev 76:296-316

Barnes SJ, David MR, Le Vaillant M, Campbell MJ, Verrall MR, Roberts MP, Noreen JE (2016b) Poikilitic textures, heteradcumulates and zoned orthopyroxenes in the Ntaka ultramafic complex, Tanzania: implications for crystallization mechanisms of oikocrysts. J Petrol 57(6):1171-1198

Barnes SJ, Fiorentini ML (2012) Komatiite magmas and sulfide nickel deposits: a comparison of variably endowed Archean terranes. Econ Geol 107(5):755-780

Barnes SJ, Halkoaho T, Papunen H, Perring C (1996) Chromite in komatiites: a comparative study of chromite in komatiites from the Forrestania greenstone belt, Western Australia, and the Pulju and Kuhmo greenstone belts, Finland. CSIRO, exploration and mining report 273R. Floreat Park, Australia, p 84

Barnes SJ, Hill RET (1995) Poikilitic chromite in komatiitic cumulates. Miner Petrol 54:85-92

Barnes SJ, Lesher CM, Sproule RA (2007) Geochemistry of komatiites in the eastern goldfields Superterrane, Western Australia and the Abitibi greenstone belt, Canada, and implications for the distribution of associated Ni-Cu-PGE deposits. Appl Earth Sci 116(4):167-187

Barnes SJ, Roeder PL (2001) The of range of spinel compositions in terrestrial mafic and ultramafic rocks. J Petrol 42(12):2279-2302

Bayanova T, Ludden J, Mitrofanov FP (2009) Timing and duration of Palaeoproterozoic events producing ore-bearing layered intrusions of the Baltic shield: Metallogenic, petrological and geodynamic implications. Geol Soc Lond, Spec Publications 323:165-198

Begg GC, Hronsky JAM, Arndt NT, Griffin WL, O’Reilly SY, Hayward N (2010) Lithospheric, cratonic, and geodynamic setting of Ni-cuPGE sulfide deposits. Econ Geol 105(6):1057-1070

Bickle MJ (1982) The magnesium contents of komatiitic liquids. In: Arndt NT, Nisbet EG (eds) Komatiites. George Allen and Unwin, London, pp 479-494

Campbell IH (1987) Distribution of orthocumulate textures in the Jimberlana intrusion. J Geol 95(1):35-53

Chai G, Naldrett AJ (1992) The Jinchuan ultramafic intrusion: cumulate of a high-Mg basaltic magma. J Petrol 33(2):277-303

Chistyakov AV, Sharkov EV (2008) Petrology of the early Paleoproterozoic Burakovsky complex, southern Karelia. Petrology 16(1):63-86

Duke JM (1986) Petrology and economic geology of the Dumont sill: an Archean intrusion of komatiitic affinity in northwestern Quebec. Geol Surv Can Economic Geol Report 35:56

Elo S (1992) Deep fractures in the Paanajärvi-Kuusamo-Kuolajärvi area. In: Silvennoinen A (ed) Deep fractures in the Paanajärvi-KuusamoKuolajärvi area. Geol Surv Finl, Spec Paper 13:43-50

Godel B, Barnes SJ, Gürer D, Austin P, Fiorentini ML (2013) Chromite in komatiites: 3D morphologies with implications for crystallization mechanisms. Contrib Mineral Petrol 165:173-189

Gole MJ, Barnes SJ (2020) The association between Ni-Cu-PGE sulfide and $\mathrm{Ni}$-Co lateritic ores and volcanic facies within the komatiites of the $2.7 \mathrm{Ga}$ east Yilgarn Craton large igneous province, Western Australia. Ore Geol Rev 116:1-21
Halkoaho T, Konnunaho J, Niskanen M (2019) Näränkävaara prospectus, Hakku database report. Geol Surv Finl, Espoo

Hanski E, Walker RJ, Huhma H, Suominen I (2001) The Os and Nd isotopic systematics of c. 2.44 Ga Akanvaara and Koitelainen mafic layered intrusions in northern Finland. Precambrian Res 109(1-2): $73-102$

Hill RET, Barnes SJ, Gole SE, Dowling SE (1995) The volcanology of komatiites as deduced from field relationships in the NorsemanWiluna greenstone belt, western Australia. Lithos 34(1-3):159-188

Hölttä P, Heilimo E, Huhma H et al (2012) Archaean complexes of the Karelia Province in Finland. Geol Surv Finl, Spec Paper 54:9-20

Huhtelin T (2015) The Kemi chromite deposit. In: Maier WD, Lahtinen J, O'Brien H (eds) Mineral deposits of Finland. Elsevier, Amsterdam, pp $165-178$

Iljina M (2003) Hanke 2106001. Pohjois-Suomen kerrosintruusiot 1996 2002 Loppuraportti. Geol Surv Finl, Report of project, 24 pp

Iljina M, Hanski E (2005) Layered mafic intrusions of the TornioNäränkävaara belt. In: Lehtinen M, Nurmi PA, Rämö OT (eds) Precambrian geology of Finland - key to the evolution of the Fennoscandian shield. Developments in Precambrian geology, vol 14. Elsevier, Amsterdam, pp 101-137

Iljina M, Maier WD, Karinen T (2015) PGE-(Cu-Ni) deposits of the Tornio-Näränkävaara belt of intrusions (Portimo, Penikat, and Koillismaa). In: Maier WD, Lahtinen J, O'Brien H (eds) Mineral deposits of Finland. Elsevier, Amsterdam, pp 134-164

Iljina M, Salmirinne H, Heikura P (2006) Tutkimustyöselostus Kuparivaaran valtauksella (7655/1) Kuusamossa suoritetuista tutkimuksista vuosina 2003-2004. Geol Surv Finl, Hakku database, Exploration report, $41 \mathrm{pp}$

Irvine TN (1982) Terminology for layered intrusions. J Petrol 23(2):127162

Järvinen V, Halkoaho T, Konnunaho J, Heinonen JS, OT Rämö (2020) Parental magma, magmatic stratigraphy, and reef-type PGE enrichment of the $2.44 \mathrm{Ga}$ mafic-ultramafic Näränkävaara layered intrusion, Northern Finland. Miner Depos 55:15351560

Karinen T (2010) The Koillismaa Intrusion, northeastern Finland - evidence for PGE reef forming processes in the layered series. Geol Surv Finl, Bull 404:176

Konnunaho JP, Hanski EJ, Bekker A, Halkoaho TAA, Hiebert RS, Wing BA (2013) The Archean komatiite-hosted, PGE-bearing Ni-Cu sulfide deposit at Vaara, eastern Finland: evidence for assimilation of external sulfur and post-depositional desulfurization. Mineral Deposita 48:967-989

Konnunaho J (2016) Komatiite-hosted Ni-Cu-PGE deposits in Finland: their characterization, PGE content, and petrogenesis. Geological Survey of Finland, Special publication 92, $38 \mathrm{pp}$

Kulikov VS, Bychkova YV, Kulikova VV, Ernst R (2010) The Vetreny Poyas (Windy Belt) subprovince of southeastern Fennoscandia: an essential component of the ca. 2.5-2.4 Ga Sumian large igneous province. Precam Res 183(3):589-601

Labtium Oy (2015) Sample preparation and analytical methods Geochemistry, exploration and mining. https://www.labtium.fi/wpcontent/uploads/2017/07/Labtium_Sample_preparation and analytical_methods.pdf

Lahtinen J (2005) Tutkimustyöselostus Näränkävaaran-Murtovaaran ultramafisella-mafisella kompleksilla valtauksilla Murtovaara 6, 8$19,21-26,32-34$ vuosina 2001-2003 suoritetuista malmitutkimuksista. Geol Surv Finl, Hakku-database, Exploration report, $9 \mathrm{pp}$

Lehtonen E, Heilimo E, Halkoaho T, Käpyaho A, Hölttä P (2016) U-Pb geochronology of Archaean volcanic-sedimentary sequences in the Kuhmo greenstone belt, Karelia Province - multiphase volcanism from Meso- to Neoarchaean and a Neoarchaean depositional basin? Precambrian Res 275:48-69 
Lehtonen E, Heilimo E, Halkoaho T, Hölttä P, Huhma H (2017) The temporal variation of Mesoarchaean volcanism in the Suomussalmi greenstone belt, Karelia Province, eastern Finland. Int J Earth Sci 106(2):763-781

Li C, Ripley EM (2005) Empirical equations to predict the sulfur content of mafic magmas at sulfide saturation and applications to magmatic sulfide deposits. Mineral Deposita 40(2):218-230

Luukkonen EJ (1989) The early Proterozoic Saari-Kiekki greenstone belt: A representative of the Sariola Group at Kuhmo, eastern Finland. Bulletin Geol Soc Finl 61(2):161-187

Makkonen HV, Halkoaho T, Konnunaho J, Rasilainen K, Kontinen A, Eilu P (2017) Ni-(Cu-PGE) deposits in Finland - geology and exploration potential. Ore Geol Rev 90:667-696

Maier WD, Halkoaho T, Huhma H, Hanski E, Barnes SJ (2018) The Penikat intrusion, Finland: geochemistry, geochronology, and origin of platinum-palladium reefs. J Petrol 59(5):967-1006

McDonough WF, Sun S-s (1995) The composition of the earth. Chem Geol 120:223-253

Mikkola P, Huhma H, Heilimo E, Whitehouse M (2011) Archean crustal evolution of the Suomussalmi district as part of the Kianta complex, Karelia: constraints from geochemistry and isotopes of granitoids. Lithos 125(1-2):287-307

Murck BW, Campbell IH (1986) The effects of temperature, oxygen fugacity and melt composition on the behaviour of chromium in basic and ultrabasic melts. Geochim Cosmochim Acta 50(9): $1871-1887$

Nakamura N (1974) Determination of REE, Ba, Fe, Mg, Na and K in carbonaceous and ordinary chondrites. Geochim Cosmochim Acta 38(5):757-775

Nikolaev GS, Ariskin AA (2005) Burakovo-Aganozero layered massif in the trans-Onega area: II. Structure of the marginal series and the estimation of the parental magma composition by geochemical thermometry techniques. Geochem Int 43(7):646-665

Nikolaev GS, Khorov DM (2003) Burakovo-Aganozero layered massif of the trans-Onega region: 1. Geochemical structure of the layered series. Geochem Int 41(8):770-786

Niskanen M, Jokinen J (2018) Näränkävaaran FrEM-syvätutkimus 2018. Geol Surv Finl, Hakku-database, Work report, 9 pp

Papunen H, Halkoaho T, Luukkonen E (2009) Archaean evolution of the Tipasjärvi-Kuhmo-Suomussalmi greenstone complex, Finland. Geol Surv Finl, Bull 403, Espoo:68

Puchtel IS, Haase KM, Hofmann AW, Chauvel C, Kulikov VS, GarbeSchönberg CD, Nemchin AA (1997) Petrology and geochemistry of crustally contaminated komatiitic basalts from the Vetreny Belt, southeastern Baltic shield: evidence for an early Proterozoic mantle plume beneath rifted Archean continental lithosphere. Geochim Cosmochim Acta 61(6):1205-1222

Rämö OT, Karinen T, Halkoaho T (2017) Nd-Sr isotopic constraints for the source of the western part of Koillismaa-Näränkävaara layered igneous complex. In: Hölttä P, Nenonen K, Eerola T (eds) 3rd Finnish National Colloquium of geosciences, Espoo, 15-16 March 2017, abstract book, Geol Surv Finl, Guide, vol 63, pp 77-78

Roeder PL, Emslie RF (1970) Olivine-liquid equilibrium. Contrib Mineral Petrol 29:275-289

Salmirinne I, Iljina M (2003) Koillismaan kerrosintruusiokompleksin tulokanavamuodostuman painovoimatulkinta ja alueen malmimahdollisuudet. Geol Surv Finl, Hakku-database, Archive Report, $23 \mathrm{pp}$

Simkin T, Smith JV (1970) Minor-element distribution in olivine. J Geol 78(3):304-325

Telenvuo B (2017) Kumulusstratigrafia ja mineraalien kryptinen vaihtelu Kuusamon Näränkävaaran kerrosintruusion luoteisosassa. MSc thesis, University of Oulu, $83 \mathrm{pp}$

Tiira T, Janik T, Kozlovskaya E et al (2014) Crustal architecture of the inverted Central Lapland rift along the HUKKA 2007 profile. Pure Appl Geophys 171(7):1129-1152

Toplis MJ (2005) The thermodynamics of iron and magnesium partitioning between olivine and liquid: criteria for assessing and predicting equilibrium in natural and experimental systems. Contrib Mineral Petrol 149:22-39

Tulenheimo T (1999) Kuhmon Kellojärven kerroksellinen ultramafinen muodostuma. MSc thesis, University of Turku, $199 \mathrm{pp}$

Vesanto J (2003) Kaivoslain 19 §:n mukainen tutkimustyöelostus Kuusamon Näränkävaaran kerrosintruusion alueella valtauksilla Murtovaara $1-5,7,20,30,31,36,37,41-71$ suoritetuista malmitutkimuksista. Geol Surv Finl, Hakku-database, Exploration report, $9 \mathrm{pp}$

Vuollo J, Huhma H (2005) Paleoproterozoic mafic dikes in NE Finland. In: Lehtinen M, Nurmi PA, Rämö OT (eds) Precambrian geology of Finland - key to the evolution of the Fennoscandian shield. Developments in Precambrian geology, vol 14. Elsevier, Amsterdam, pp 195-236

Wager LR, Brown GM, Wadsworth WJ (1960) Types of igneous cumulates. J Petrol 1(1):73-85

Walker D, Jurewicz S, Watson EB (1988) Adcumulus dunite growth in a laboratory thermal gradient. Contrib Mineral Petrol 99:306-319

Wilson AH (1982) The geology of the great dyke, Zimbabwe: the ultramafic rocks. J Petrol 23(2):240-292

Yang S-H, Hanski E, Li C et al (2016) Mantle source of the 2.44-2.50-Ga mantle plume-related magmatism in the Fennoscandian Shield: evidence from $\mathrm{Os}, \mathrm{Nd}$, and $\mathrm{Sr}$ isotope compositions of the Monchepluton and Kemi intrusions. Mineral Depos 51(8):10551073

Publisher's note Springer Nature remains neutral with regard to jurisdictional claims in published maps and institutional affiliations. 